\title{
Bird sensitivity to disturbance as an indicator of forest patch conditions: An issue in environmental assessments
}

\author{
Eduardo Roberto Alexandrino ${ }^{\mathrm{a}, *}$, Evan R. Buechley ${ }^{\mathrm{b}}$, Augusto João Piratelli ${ }^{\mathrm{c}}$, \\ Katia Maria Paschoaletto Micchi de Barros Ferraz ${ }^{\mathrm{a}}$, Rafael de Andrade Moral ${ }^{\mathrm{d}}$, \\ Çağan H. Şekercioğlu ${ }^{\mathrm{b}}$, Wesley Rodrigues Silva ${ }^{\mathrm{e}}$, Hilton Thadeu Zarate do Couto ${ }^{\mathrm{a}}$
}

\footnotetext{
a Laboratório de Ecologia, Manejo e Conservação de Fauna Silvestre - LEMaC e Laboratório de Métodos Quantitativos - LMQ Departamento de Ciências Florestais, Escola Superior de Agricultura “Luiz de Queiroz”, Universidade de São Paulo, campus Piracicaba, Av. Pádua Dias n.11, CEP 13418-900, Piracicaba, SP, Brazil

b Biodiversity and Conservation Ecology Lab, Department of Biology, University of Utah, 257 South 1400 East, Salt Lake City, UT 84112-0840, USA

c Centro de Ciências e Tecnologias para a Sustentabilidade - CCTS, Departamento de Ciências Ambientais, Universidade Federal de São Carlos - UFSCar, campus Sorocaba, Rod. João Leme dos Santos, Km 110, CEP 18052-780, Sorocaba, SP, Brazil

${ }^{\mathrm{d}}$ Departamento de Ciências Exatas - Universidade de São Paulo. Escola Superior de Agricultura "Luiz de Queiroz", Universidade de São Paulo, campus Piracicaba, Av. Pádua Dias n.11, CEP 13418-900 Piracicaba, SP, Brazil

e Laboratório de Interações Vertebrados-Plantas, Departamento de Biologia Animal, Instituto de Biologia, Universidade Estadual de Campinas, CP 6109, CEP 13083-970 Campinas, SP, Brazil
}

\section{A R T I C L E I N F O}

\section{Article history:}

Received 18 June 2015

Received in revised form 25 January 2016

Accepted 1 February 2016

Available online 18 February 2016

\section{Keywords:}

Atlantic Forest fragments

Agricultural landscapes

Bioindicator

Environmental impact assessment

Environmental conditions

Ecological indicator

Bird conservation

Ornithological analysis

Neotropics

\begin{abstract}
A B S T R A C T
An Environmental Assessment (EA) is one of the steps within the Environmental Impact Assessment process. Birds are often used in EA to help decision makers evaluate potential human impacts from proposed development activities. A "sensitivity to human disturbance" index, created by Parker III et al. (1996) for all Neotropical species, is commonly considered an ecological indicator. However, this parameter was created subjectively and, for most species, there have been no rigorous field test to validate its effectiveness as such. Therefore, in this study, we aim to: (1) evaluate if, at the local scale, birds from forest patches in a human-modified landscape (HML) may differ in sensitivity from Parker's sensitivity classification; (2) evaluate the effectiveness of the species richness value at each sensitivity level as an ecological indicator; (3) gather information on how often and in which manner Parker's classification has been used in EA. To do so, bird sampling was performed in eight forest patches in a HML over one year. Then, we created a local sensitivity to disturbance using information about threat, endemism, spatial distribution and relative abundance of all species in the study area. We found that $37 \%$ of the forest birds showed different local sensitivity levels when compared with Parker's classification. Our results show that only the richness of high-sensitivity species from our local classification fitted the ecological indicator assumptions helping the environmental conditions evaluation of the studied patches. We conclude that species richness of each Parker's bird sensitivity levels do not necessarily perform as an ecological indicator at the local scale, and particularly in HML. Nevertheless, Parker's Neotropical bird sensitivity classification was used in 50\% of EA we reviewed. In these, $76 \%$ assumed that it was an accurate ecological indicator of the local forest conditions for birds. The lack of clear criteria used in Parker's classification allows diverse interpretations by ornithologists, and there is no agreement about the ecological meaning of each sensitivity level and what environmental conditions each level may indicate of. Therefore, the use of Parker's classification in EA may jeopardize accurate interpretations of proposed anthropogenic impacts. Furthermore, because a bird species' sensitivity often varies between locations, we argue that Parker's generalized classification of bird sensitivity should not be used as an indicator of forest environmental conditions in EA throughout HMLs in Neotropics. Rather, local bird ecological indices should be explored, otherwise, erroneous predictions of the anthropogenic impacts will continue to be common.
\end{abstract}

(c) 2016 Elsevier Ltd. All rights reserved.

\footnotetext{
* Corresponding author.

E-mail addresses: eduardoalexandrino@hotmail.com (E.R. Alexandrino), e.buechley@utah.edu (E.R. Buechley), piratelli@ufscar.br (A.J. Piratelli), katia.ferraz@usp.br

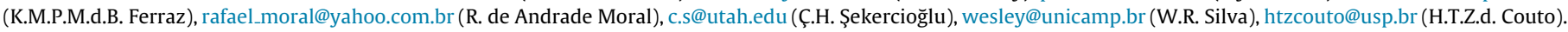




\section{Introduction}

Human impacts on natural ecosystems are ubiquitous, environmentally damaging, and likely to continue for the foreseeable future (Vitousek et al., 1997; Foley et al., 2005). One important tool to minimize and regulate these impacts is the Environmental Impact Assessment (hereafter EIA) (Glasson and Salvador, 2000; Carroll and Turpin, 2002; Slootweg and Mollinga, 2010; Sánchez and Croal, 2012). An EIA is a multidisciplinary and systematic process of evaluating and mitigating the impacts of proposed human development actions, such as industries, housing, infrastructure, mining, agriculture, etc. (Kolhoff et al., 2010; Sánchez and Croal, 2012). An EIA typically includes a multidisciplinary Environmental Assessment (hereafter EA), which includes an assessment of the biodiversity occurring in a given area where a potential impact will occur (CONAMA Resolution 001/86, CONAMA Resolution 237/1997, SMA Resolution 49/2014 but see Glasson and Salvador, 2000). In Brazil, as in many countries (Rajvanshi et al., 2010), this biodiversity assessment component is meant to help decision makers evaluate the possible environmental consequences of development activities (Glasson and Salvador, 2000; Silveira et al., 2010; Sánchez and Croal, 2012).

The EA is often limited by funding and time constraints (Thompson et al., 1997; Vasconcelos, 2006; Rajvanshi et al., 2010; Silveira et al., 2010). Thus, the selection of ecological indicator species can help to expediently assess the ecological condition of the environment under study (e.g., Temple and Wiens, 1989; Dale and Beyeler, 2001; Niemi and McDonald, 2004; Syrbe et al., 2013), as they may act as a surrogate measurement of other biological groups not accessed (Carignan and Villard, 2002; Niemi and McDonald, 2004). Birds are frequently used as indicator species (Byron, 2000; Vasconcelos, 2006; Silveira et al., 2010; Straube et al., 2010; Chang et al., 2013), because they are relatively easy to sample in the field (Gardner et al., 2008), and they are good indicators of habitat quality (e.g., Temple and Wiens, 1989; Stotz et al., 1996; Bradford et al., 1998; Canterbury et al., 2000; Carignan and Villard, 2002; Sutherland et al., 2004; Sekercioglu, 2006, 2012; Chambers, 2008). The landmark book "Neotropical Birds: Ecology and Conservation" by Stotz et al. (1996) includes a database with a variety of biological and ecological parameters for all bird species in the Neotropics (see database A, hereafter referenced as Parker III et al., 1996, as recommended by the authors). Herein, the authors highlight that species are differentially vulnerable to human disturbance. They rank each Neotropical bird species' "sensitivity to disturbance", as "high", "medium" or "low". A common interpretation of this parameter is to deem the occurrence of birds of high-sensitivity at a given site as an indication of good environmental conditions (e.g., Anjos, 2006; Anjos et al., 2009, 2010; Loures-Ribeiro et al., 2011). Consequently, this theoretical assumption fits the requirements of the Brazilian environmental legislation (item I, article $5^{\circ}$ IBAMA Normative Instruction n.146/2007), which suggest biodiversity inventories in EA use ecological indicators (CONAMA Resolution 001/86, Straube et al., 2010). However, there is uncertainty as to how the "sensitivity to disturbance" parameter is representative of the ecological condition of a given site when used in this manner.

The "sensitivity to disturbance" parameter was created over 25 years ago. It was based on the authors' expertise, as well as reports and experience from other ornithologists about the relative frequency (high, medium, or low) of each species found in association with disturbed patches of its preferred habitat (J.W. Fitzpatrick personal communication, but see "Guide to the databases" on Parker III et al., 1996). While it was a groundbreaking and highly instructive work in 1996, there is considerable subjectivity in the rankings, and there is now significant evidence that it may be outdated or flawed. For example, some species listed as medium-sensitivity (e.g., Picazuro Pigeon - Patagioenas picazuro; Flavescent Warbler - Myiothlypis flaveola) and high-sensitivity (e.g., Gray-necked Wood-Rail - Aramides cajaneus; Uniform Finch - Haplospiza unicolor; Pavonine Cuckoo - Dromococcyx pavoninus; Red-crowned Ant-Tanager - Habia rubica) are frequently reported at highly impacted sites such as cities and agricultural landscapes (e.g., Willis and Oniki, 1987, 2002; Pozza and Pires, 2003; Franz et al., 2010; Cruz and Piratelli, 2011; Ferraz et al., 2012; Alexandrino et al., 2013). Thus, in order to assess the validity of using Parker's classification, it is important to evaluate whether species respond to human disturbance as expected from this parameter. Besides, taking into consideration that a species conservation status may vary at different geographical scales (Milner-Gulland et al., 2006; Brito et al., 2010), we may question whether the pan-Neotropical scale used in Parker's classification can efficiently reflect the status of a species' population at regional or local scales.

Henle et al. (2004) warn that interactions of species traits and environmental conditions must be considered to predict species sensitivity to human disturbance or habitat fragmentation, a procedure not used in Parker's classification. Only two studies have tested the consistency of Parker's "sensitivity to disturbance" classification in representing the effects of forest habitat loss and fragmentation on birds in Atlantic Forest patches (Ribon et al., 2003; Anjos, 2006). Besides, there is relatively little research assessing the variability in sensitivity of forest birds to anthropogenic disturbances and fragmentation effects at local scales in human-modified landscapes (HML) (e.g., Ribon et al., 2003; Anjos, 2006; Piratelli et al., 2008; Anjos et al., 2009, 2010, 2011; Loures-Ribeiro et al., 2011). This contributes to uncertainty about using Parker's classification in EAs.

Therefore, we test if, at the local scale, forest bird species from patches in a HML may show different levels of sensitivity to disturbance than Parker's classification. To do so, we developed a local metric of sensitivity to disturbance using threat status, endemism, spatial distribution and relative abundance of the species in the study area. We then evaluate the effectiveness of using Parker's classification as an ecological indicator of the effects of the forest habitat loss and fragmentation, by comparing the two classifications. Finally, we review the frequency and manner of use of Parker's classification in EA from a wide range of projects that were environmentally licensed in the last two decades. We conclude with a discussion of the shortcomings of and risk associated with using Parker's classification in EA.

\section{Materials and methods}

\subsection{Study site selection}

Field surveys were conducted in the Corumbataí River basin, in east-central São Paulo State $\left(22^{\circ} 04^{\prime} 46^{\prime \prime}\right.$ S to $22^{\circ} 41^{\prime} 28^{\prime \prime}$ S; $47^{\circ} 26^{\prime} 23^{\prime \prime}$ $\mathrm{W}$ to $47^{\circ} 56^{\prime} 15^{\prime \prime} \mathrm{W}$ ), Brazil (Fig. 1). This river basin was originally covered by semi-deciduous seasonal forest (Atlantic forest biome) and sparse savannah woodland (Cerrado biome). However, after years of human modification, it is now composed of small (e.g., Charqueada with around $\sim 15,000$ inhabitants) to medium cities (e.g., Rio Claro with 200,000 inhabitants) (IBGE, 2015) surrounded by a predominantly agricultural mosaic. Of the $1710 \mathrm{~km}^{2}$ in the river basin, $44 \%$ is cattle pasture (located mostly in the north), $26 \%$ is sugar cane (mostly in the south), $11 \%$ is native forest, and $0.7 \%$ is savannah woodland (Valente and Vettorazzi, 2003). The native forest is in small, isolated patches throughout the basin (Valente and Vettorazzi, 2003; e.g., Ferraz et al., 2014). This region is representative of the Brazilian agricultural landscapes that are found within the original boundaries of the Interior Atlantic Forest biome 

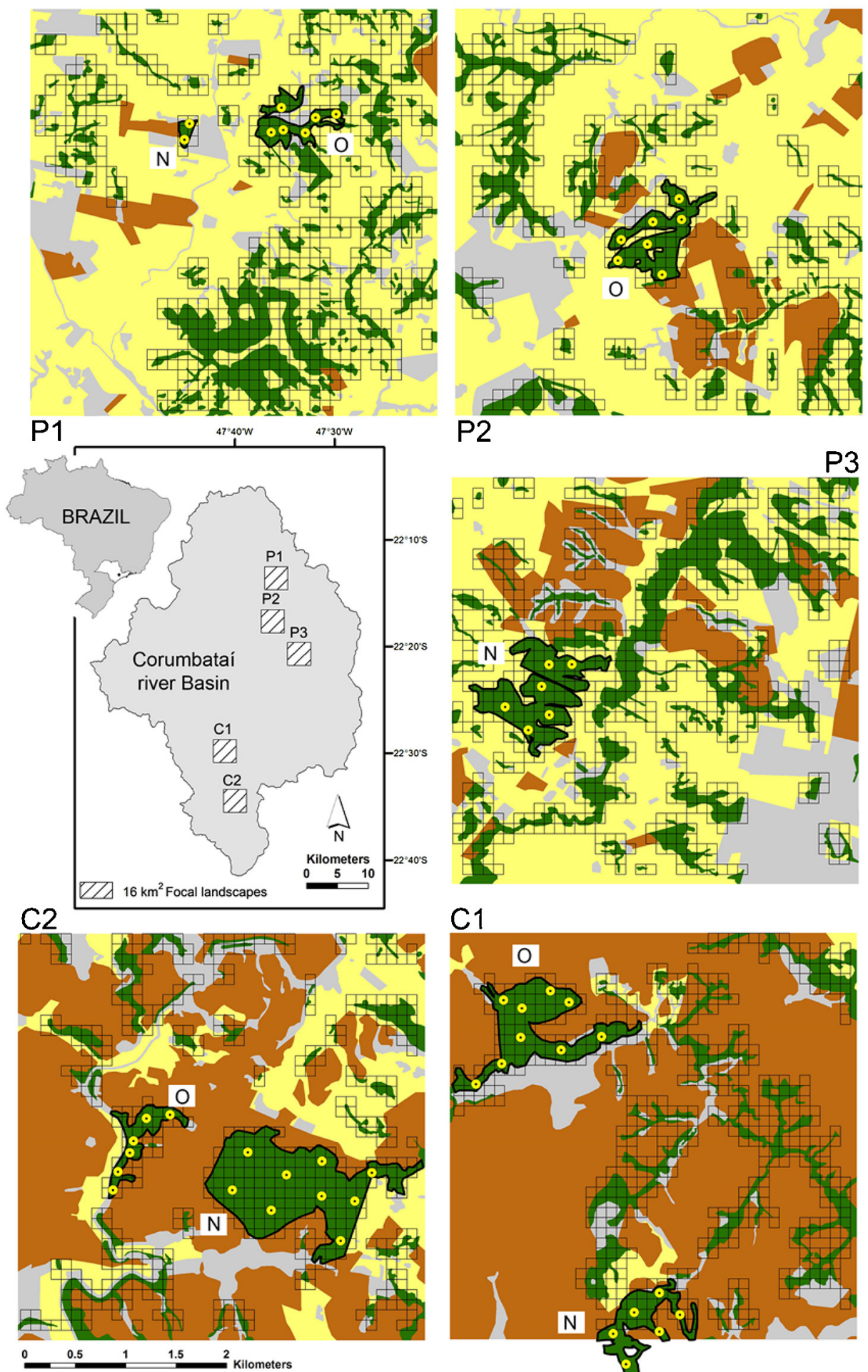

C1

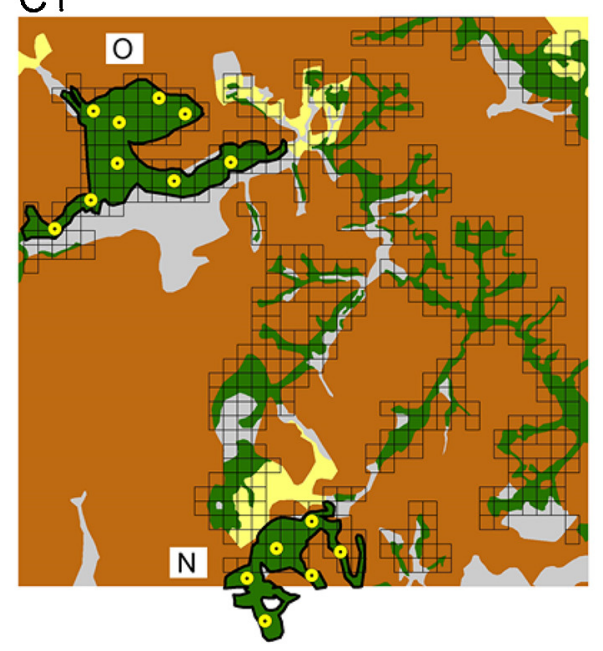

Pasture Sugar cane

Forest pacthes

Others

$\square$ 1ha subdivisions - rank of ecosystem services (Ferraz et al. 2014)

$\odot$ Point counts

Fig. 1. Focal landscapes $\left(16 \mathrm{~km}^{2}\right)$ of the Corumbataí River Basin (São Paulo State, southeast Brazil) and the eight forest patches selected for this study (outlined in black). The letters beside the selected patches indicate for how long the patch major amount is in the landscape. ( $\mathrm{N}$ - patch predominantly new, $\mathrm{O}$ - patch predominantly old) (see Appendix A). "P" means pasture matrix and "C" means sugar cane matrix. The numbers designate the name of each patch selected (e.g., C1N, C1O, C2N, etc.). Land use follows Ferraz et al. (2014). 
(e.g., Ferraz et al., 2014; see Silva and Casteleti, 2003 for further details of the existing biome subdivisions).

In this study, we selected forest patches in five of the six focal landscapes studied by Ferraz et al. (2014) in this HML (Fig. 1). Each focal landscape is $16 \mathrm{~km}^{2}$, and includes $>70 \%$ agricultural matrix (sugar cane or pasture) and $>10 \%$ native forest. We excluded one focal landscape used by Ferraz et al. (2014), which was located in a sugar cane matrix, because there were no forest patches that we could sample according to our following selection criteria. For selection of sites, we first used historical images from 1962, 1978, 1995,2000 and 2008 to identify the predominant age of each forest patch (i.e., for how long the major amount of the patch is present in the landscape). Next, we verified in the field which patches had forest cover matching the most recent satellite image. We also assessed the expected age of succession of the forest (e.g., DeWalt et al., 2003; Chazdon et al., 2007), and its accessibility. We selected patches that had matching forest succession expected from its predominant age and those which were realistically accessible (i.e., located on public land or on private land with access permission from the landowner). Then, four old patches (the major part of the patch is present on the river basin since 1962 or 1978 images) and four new patches (the major part of the patch was absent in the 1962 and 1978 images and its regeneration started mainly in or after 1995) were selected (see Appendix A). Two patches of each age class were selected in each matrix category (pasture at north and sugarcane at south), for a total of eight patches (Fig. 1). This procedure was adopted because studies have shown that the historical degradation of forest patches (Metzger et al., 2009; Lira et al., 2012) and the matrix type (Prevedello and Vieira, 2010) are two driving factors behind bird community composition in HML.

\subsection{Bird surveys}

Both point count and transect methods were used for bird surveys (Bibby et al., 2000; Vielliard et al., 2010). Using ArcGIS 9.0, point counts were positioned inside the selected patches randomly and at least $200 \mathrm{~m}$ apart to avoid redundant samples (e.g., Uezu et al., 2008). The number of points was proportionally allocated in each forest patch by area (e.g., two points in the smallest, nine points in the largest) (Fig. 1). A total of 51 point counts were used. Each point was visited 12 times by a trained observer and sampling took place once per month over November 2011 to November 2012. Point counts lasted $10 \mathrm{~min}$, with an unlimited detection radius (e.g., Anjos et al., 2004; Uezu et al., 2005) but we only considered valid records from species heard or seen in the interior or forest edge (up to canopy). We used the accumulated number of contacts (i.e., each auditory or visual record from distinct individuals) of each species in each point count as a measure of abundance (e.g., Anjos et al., 2004; Bibby et al., 2000; Vielliard et al., 2010). While conducting point counts, the observer paid constant attention of the direction of visual or audio detection and recorded each contact in a field notebook each 2 min (see notebook page example in Appendix B). These procedures enabled the observer to check if each detection in the field belonged to a new individual or could belong to an already counted individual along the $10 \mathrm{~min}$ sampling, helping to avoid recounts. Because of this precaution, when a flock was observed we counted the number of individuals in the flock as many as possible. Transects were allocated in order to connect the point counts in a same patch and they roamed the interior and forest edge depending the point counts position and the field accessibility (see Appendix A). The observer speed walk in transects were not standardized and because of this we only used transect data to complement the bird species list of each patch. The samplings were interrupted during the movement between points located in different patches, which was done by car. Only the period from the sunrise up to $11 \mathrm{am}$ was used, which allowed a mean of six point visited by field day.
In order to avoid sampling bias, the sequence of the point counts sampled was always drawn before the beginning of the fieldwork, and rainy days were not used for sampling. Nomenclature and taxonomic order follow those of the Brazilian Ornithological Records Committee (Comitê Brasileiro de Registros Ornitológicos, 2014).

\subsection{Local sensitivity to disturbance for forest species}

We created a local "sensitivity to disturbance" metric in order to compare with Parker's pan-Neotropical classification, using the same levels of high, medium, and low sensitivity. For this metric we assumed the scale of our analysis to be "local", based on our study area of $16 \mathrm{~km}^{2}$ in five focal landscapes. Although the sensitivity in Parker III et al. (1996) does not have a clear definition with respect to the type of human disturbance considered, we assumed that this classification was created based on avian responses to the loss and fragmentation of natural habitats. This was the same assumption used by previous studies that also made comparisons with Parker's classification (Ribon et al., 2003; Anjos, 2006). In addition, since Parker's classification did not have a clear definition of what each level of sensitivity means, we developed our classification based on the knowledge provided by previous studies in the Atlantic Forest biome, which also tested the sensitivity of forest birds to the effects of the forest habitat loss and fragmentation at local scales (e.g., Ribon et al., 2003; Anjos, 2006; Piratelli et al., 2008; Anjos et al., 2009, 2010; Loures-Ribeiro et al., 2011).

We assume that "forest species" are those that prefer at least one Neotropical forest habitat, following the "habitat" parameter used in Parker III et al. (1996). Although we are investigating potential problems with the "sensitivity to disturbance" measure of Parker III et al. (1996), we recognize that they provide extensive valuable ecological knowledge about Neotropical birds. Due to their long period of study and the authors' accumulated expertise, they have distinguished 41 Neotropical habitat categories based on how birds appear to use different vegetation types. They considered different categories of forest $(F)$, non-forest (NF) and aquatic Neotropical habitats $(\mathrm{A})$ and assigned for each species their preferred habitats. However, some species may occur in more than one habitat type (Appendix C). Thus, all species that occur in any forest $(F)$, forest and non-forest (F-NF) or forest and aquatic (F-A) habitats (Alexandrino et al., 2013, see Appendix C) are considered here as forest birds.

Initially, we identified threatened species in São Paulo State (Silveira et al., 2009) and Cerrado and Atlantic Forest biome endemic species (Bencke et al., 2006), because these groups are often considered to be highly sensitive to anthropogenic impacts (Goerck, 1997; Ribon et al., 2003; Anjos et al., 2010). Then, we ran Indicator Species Analysis (hereafter ISA) (Dufrêne and Legendre, 1997) through the Monte Carlo test $(\alpha=1 \%)$ in the PCOrd 4.01 package (McCune and Mefford, 1997) as performed in Piratelli et al. (2008). This analysis combines the frequency of occurrence (days of occurrence on each patch, data from transect and point counts) and abundance of each species (accumulated number of contact on each patch provided by 51 point counts) to generate the Indicator Value (hereafter IV), which indicates the percentage of the individuals of each species that occur in each forest patch. This IV is validated by statistical comparisons of observed results against the IV obtained through randomization of the field data (Dufrêne and Legendre, 1997). An ISA test with a significant result (i.e., from the Monte Carlo test $F<0.01$ ) identifies species that have non-random distributions among the patches, suggesting their preference for some over others. Conversely, species with an ISA test that is not statistically significant are considered randomly distributed among the forest patches and without preference. We assume that species associated with only a few patches, as indicated by the IV, have restricted viable populations. This follows the assumption that such species are likely to be more sensitive to disturbance than other 
Table 1

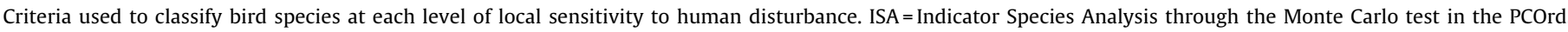
IV = Indicator Value obtained from ISA test.

\begin{tabular}{|c|c|}
\hline Sensitivity levels & Classification criteria \\
\hline High & $\begin{array}{l}\text { Species cited in some threat status category (independent of their abundance and/or frequency of occurrence), plus endemic species with } \\
\text { non-random distribution among the patches with IV for 1-3 patches, as indicated by the ISA test }\end{array}$ \\
\hline Medium & $\begin{array}{l}\text { Endemic species with non-random distribution among the patches with IV for } 4-5 \text { patches, plus non-endemic and non-threatened species } \\
\text { with non-random distribution among the patches with IV for } 1-5 \text { patches }\end{array}$ \\
\hline Low & $\begin{array}{l}\text { Endemic, non-endemic and non-threatened species with non-random distribution among the patches with IV for 6-8 patches, plus species } \\
\text { with ISA test not statistically significant (except forest specialist species with field records on four patches or less) }\end{array}$ \\
\hline
\end{tabular}

species that are widely distributed on the sampled sites (Anjos, 2006; Piratelli et al., 2008). In our study, we are not concerned with which patch has higher IV for each species. Instead, we are interested in the numbers of patches with significant individual occurrence as indicated by the IV (i.e., IV different from zero). Thus, to develop a reliable sensitivity classification for forest species, we used the ISA results, and endemism and threat status information (Table 1).

Threatened species were automatically classified as highsensitivity independent of their quantitative data. A regional list of threatened species (e.g., at the state scale) takes into account the habitat conditions and resources used by the species, as well as existing anthropogenic threats in that region (e.g., habitat loss, habitat fragmentation, urban and agricultural expansion, etc) that exert pressure on the habitats and species populations (Gärdenfors et al., 2001; Bressan et al., 2009). Therefore, even if we observed a wide distribution of a threatened species among the sampling sites, we recognize that these species are in a critical situation on a larger scale. Besides, sites harboring threatened forest species probably have good forest habitat and resources that are infrequent in fragmented landscapes (e.g., Ribon et al., 2003; Bencke et al., 2006; Mendonça et al., 2009), which help to support those species in HMLs. Consequently, the threat status is a useful tool for creating a local classification of the sensitivity to the effects of the forest loss and fragmentation (Henle et al., 2004; Hockey and Curtis, 2009).

Although some studies have considered Atlantic Forest and Cerrado endemic birds as sensitive to forest habitat loss and fragmentation (Goerck, 1997; Ribon et al., 2003; Anjos et al., 2010), Loures-Ribeiro et al. (2011) did not find them to be necessarily more sensitive to fire disturbance caused by humans in a large forest patch. Besides, our study area is not a center of endemism for species of the Atlantic Forest (see Silva et al., 2004) and is located on the edge of the Cerrado biome where very small and few forest remnants are found (see Silva and Bates, 2002; Kronka et al., 2005). Thus, many endemic species observed here may also be found in these large biomes (Bencke et al., 2006; but see MottaJunior et al., 2008; Cavarzere et al., 2011; Lima, 2013). These factors do not allow us to assume that all endemic species have the same tolerance to forest loss and fragmentation, and because of this, we also considered their distribution among the studied patches.

In order to avoid cases of vagrant species and problems associated with bias in the detectability of species documented in low numbers (Thompson, 2002), only species with at least five accumulated contacts during the one year sampling effort were considered for the ISA procedure. Also, all species with a non-significant ISA test were analyzed in order to identify their distribution among the patches. This procedure avoids cases of species observed only in a few patches but with uniform observations among them, which may cause an ISA result to be insignificant. Thus, species recorded in four patches or less were excluded from our classifications, as it was not safe to assign a low local sensitivity value to them based on limited available data (see Table 1 for the low-sensitivity level criterion). Also, all non-forest species (i.e., the aquatic and/or non-forest species following Alexandrino et al., 2013 classification criteria, see Appendix C) were excluded from our classification.

\subsection{Local measurement of forest environmental conditions}

To assess the potential of each sensitivity level (by local and Parker's classification) acting as an ecological indicator in our forest patches, we used the rank of ecosystem service provisioning, provided by Ferraz et al. (2014) for each 1 ha of our patches as a measurement of the forest environmental conditions. This rank ranges from 3 (low ecosystem services supply) to 13 (high ecosystem services supply) in our study area, and considers the history of degradation and re-growth of each forest patch (i.e., mean forest age) and landscape features (i.e., local forest neighborhood dominance, forest proximity and forest contiguity). Each of these environmental factors is also expected to drive differences in forest bird assemblages in tropical forest habitats (Table 2). Besides, Ferraz et al. (2014) assumed that forest ecosystem services performance is directly related to the forest structure, composition, and functioning (Martin et al., 2013), as well as the landscape context, such as available habitat, fragmentation, degree of isolation, and the intensity of edge effects (Banks-Leite et al., 2011). Because of this, we assume that this ranking is a viable quantification of the existing effects of the forest habitat loss and fragmentation on bird assemblages in our studied forest patches (e.g., Laurance et al., 2002; Fahrig, 2003). Therefore, forest points with lower scores have elevated levels of habitat loss and fragmentation (poor forest environmental conditions), while those with higher scores are suffering fewer effects (i.e., better forest environmental conditions).

Thus, each forest species from the point count data was classified by both Parker's and our local classification. Our objective was to check whether there was a significant relationship between the rank of ecosystem service provisioning and the species richness of each classification type and their levels of sensitivity. We assumed that species richness $Y_{k}$ for the $k$-th rank, $k=3, \ldots, 13$ followed a Poisson distribution with mean $\mu_{k}$. We then fitted Poisson regression models (McCullagh and Nelder, 1989) with the linear predictor written as $\log \left(\mu_{k}\right)=\beta_{0}+\beta_{1} r_{k}, r_{k}$ being the $k$-th rank. Finally, using likelihood-ratio tests, we tested whether $\beta_{1}$ (i.e., the slope of the linear predictor) was equal or statistically different from zero $(p=0.05)$. If $\beta_{1}$ was significantly different from zero it meant that there was a relationship between the variables. Goodness-of-fit was assessed using half-normal plots with simulation envelopes (Demétrio et al., 2014). All analyses were carried out using statistical software R (R Development Core Team, 2014). For these analyses three point counts located very close to the edge of the $\mathrm{C} 1$ focal landscape were not used since the ranking score was not available (see C1 map on the Fig. 1).

We expected that the richness of high-sensitivity species would have a strong positive relationship with the ranking of ecosystem service provisioning (regression slope $>0$ ), as sites with less forest degradation should harbor more forest specialist species (e.g., Anjos, 2006; Develey and Martensen, 2006; Martensen et al., 2012; Antunes et al., 2013). On the contrary, we expected no relationship between the richness of low-sensitivity species and the ranking (slope $=0$ ), as these species should occur in any forest environmental condition (e.g., Anjos, 2006; Franz et al., 2010; Martensen et al., 2012). For the medium-sensitivity level we expected an 
Table 2

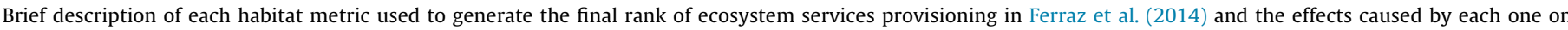

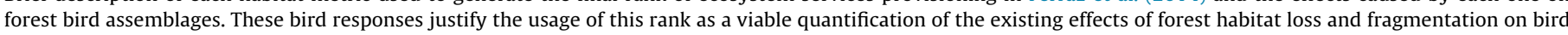
assemblages in our studied forest patches.

\begin{tabular}{|c|c|}
\hline Habitat metric calculated for each 1 ha forest portion & Effect on forest birds \\
\hline $\begin{array}{l}\text { Mean Forest Age - Each portion of the fragment has a different history of } \\
\text { deforestation and re-growth. This metric was defined by temporal } \\
\text { overlaying of land cover maps from different years, using the difference } \\
\text { between the most recent date and the first year of forest occurrence on the } \\
\text { map from the past. Old forest portions meant a better final rank score. }\end{array}$ & $\begin{array}{l}\text { The current bird occurrence in forest patches is related to the distinct } \\
\text { trajectories of the forest cover and landscape dynamics (Metzger et al., 2009; } \\
\text { Lira et al., 2012) as well as the age of the forest patch (Brooks et al., 1999a, } \\
\text { Durães et al., 2013) and their successional stage (e.g., Loures-Ribeiro et al., } \\
\text { 2011; Modena et al., 2013). }\end{array}$ \\
\hline $\begin{array}{l}\text { Local forest neighborhood dominance - Each } 1 \text { ha forest cell had eight } \\
\text { surrounding } 1 \text { ha cells measured in order to calculate the proportion covered } \\
\text { by forest. In general, full forest cells surrounded by other full forest cells } \\
\text { meant a better final rank score. Thus, this metric takes into account the } \\
\text { portion position in the forest (e.g., interior or edge). }\end{array}$ & $\begin{array}{l}\text { Bird assemblage composition and richness in interior and edge of forest } \\
\text { patches may be contrasting (e.g., Candido Jr. 2000; Manu et al., 2007; } \\
\text { Hansbauer et al., 2008a, Banks-Leite et al., 2010; Zurita et al., 2012). }\end{array}$ \\
\hline $\begin{array}{l}\text { Forest proximity - This metric was used as surrogate of local forest patch } \\
\text { connectivity. The mean proximity index (McGarical and Marks 1995) was } \\
\text { calculated for each } 1 \text { ha forest cell in relation to the other forest patches } \\
\text { present in a } 2 \mathrm{~km} \text { surrounding buffer. Thus, forest portions relatively more } \\
\text { connected to the other patches have a better final rank score. }\end{array}$ & $\begin{array}{l}\text { The patch isolation degree may influence the forest bird species movement } \\
\text { through the landscape (e.g., Awade and Metzger, 2008; Boscolo et al., 2008; } \\
\text { Martensen et al., 2008; Marini, 2010; Boscolo and Metzger, 2011), } \\
\text { consequently influencing the colonization process on the patches (e.g., Stouffer } \\
\text { et al., 2009), which will results in the current species recorded in the patches } \\
\text { (e.g., Anjos et al., 2004; Anjos, 2006; Manu et al., 2007; Martensen et al., 2012). }\end{array}$ \\
\hline $\begin{array}{l}\text { Forest contiguity - This metric takes into account for each forest cell the } \\
\text { relative size of the forest patch in relation to the focal landscape studied } \\
\left(16 \mathrm{~km}^{2}\right) \text {. Therefore, a forest cell located within a larger forest patch gets a } \\
\text { better final rank score. }\end{array}$ & $\begin{array}{l}\text { Forest patch size drives differences in bird assemblage occurrence (Anjos and } \\
\text { Boçon, 1999; Stratford and Stouffer, 1999; Anjos et al., 2004; Anjos, 2006; } \\
\text { Manu et al., 2007; Martensen et al., 2008; Uezu and Metzger, 2011; Zurita and } \\
\text { Bellocq, 2012). }\end{array}$ \\
\hline
\end{tabular}

intermediate result between the high and low relationship, i.e., a slightly positive relationship with the ranking (slope $>0$ ), but with lower slope value than the high level.

\subsection{Parker's classification in environmental assessments}

We reviewed the bird inventories of 50 EA produced between 1996 and 2013 (Appendix D). These assessments, known in Brazil as "Estudos de Impactos Ambientais/Relatório de Impacto Ambiental" and "Relatório Ambiental Preliminar" (Glasson and Salvador, 2000; CONAMA Resolution 001/86, CONAMA Resolution 237/1997, SMA Resolution 49/2014), were selected randomly at the CETESB library (Environmental Company of the State of São Paulo, responsible for the issuing of environmental licenses in this state), where all such assessments are stored. The EIA process differs between states in Brazil (Glasson and Salvador, 2000), which may change the results from biodiversity inventories according to the different requirements of each state. Thus, we focused our analysis only on EA completed within São Paulo State. Except for the southeastern part of the state, where a large area of preserved native Atlantic Forest still has full protection (Ribeiro et al., 2009), most of the original Atlantic Forest that covered São Paulo State has been converted to patches of secondary growth forest in an agricultural matrix (Victor et al., 2005; Ribeiro et al., 2009). Most EIAs in this state have been conducted in HML (e.g., Sánchez and Silvia-Sánchez, 2008, but see Appendices D and E), similar to our study site. Thus, we believe it appropriate to make inferences from our findings about Parker's classification to these EAs.

First, we checked which EAs used Parker's classification in bird data analysis. For each study that used this classification, we identified the percentage of species from each sensitivity level that were recorded in the field. We then critically read the EAs to answer the following questions: (1) Was forest bird sampling done to assess forest environmental conditions? (2)Were conclusions made about forest environmental conditions based on Parker's classification levels? (3) Did the ornithologists conducting these studies express any concern or disagreement with some aspect of Parker's classification? The answers to these questions were used to understand to what extent Parker's classification has been used as an ecological indicator of environmental conditions of forest patch in EAs.

\section{Results}

\subsection{Local sensitivity to disturbance for forest species}

In 447 observation hours, we documented 191 species, 144 of which are forest species (see Appendix $\mathrm{F}$ for the rarefaction curves for each sampled patch). Our local classification included eight threatened species and 13 endemic species (one of Cerrado and 12 of Atlantic Forest). Additionally, there were 103 forest species with at least five records in point counts, which were included in the ISA test. Forty-seven species showed non-random distributions between patches, while 56 had a non-significant ISA test result, indicating a random distribution between patches (Appendix $G$ ). From these, eight forest species (Elaenia mesoleuca, Hemithraupis guira, Malacoptila striata, Mesembrinibis cayennensis, Saltator similis, Turdus rufiventris, Turdus subalaris and Veniliornis spilogaster) with field records in four or fewer patches were excluded from our classification because their non-significant ISA results were caused by their uniform presence among these patches. Therefore, after filtering these species, 100 forest species were considered in our local sensitivity classification, comprising $70 \%$ of all forest species sampled and $52.3 \%$ of all species recorded in the field. The other 44 forest species were not considered in our classification, because they had fewer than five records and they were neither threatened nor endemic.

By comparing our local classification with Parker's classification, we found that $63 \%$ locally classified forest species showed a same level of sensibility proposed by Parker, while $37 \%$ was classified in different levels. Both classifications indicated that our forest bird assemblage was comprised primarily of low-sensitivity species. However, more species were classified in this category with the local classification ( $63 \%$ by Parker's, $75 \%$ by local) (Fig. 2 ). Of those assigned in a different sensitivity level, 20 species were classified in lower levels and 17 in higher levels when compared with Parker's. Three low-sensitivity species (Bubo virginianus, Chiroxiphia caudata and Hemithraupis ruficapilla) and nine medium-sensitivity species (Amazona aestiva, Antilophia galeata, Campephilus robustus, Cyanoloxia brissonii, Drymophila ferruginea, Lanio penicillatus, Leptodon cayanensis, Mackenziaena severa and Penelope superciliaris) in Parker's classification changed to high-sensitivity in our local classification. These changes were due to the eight threatened species 


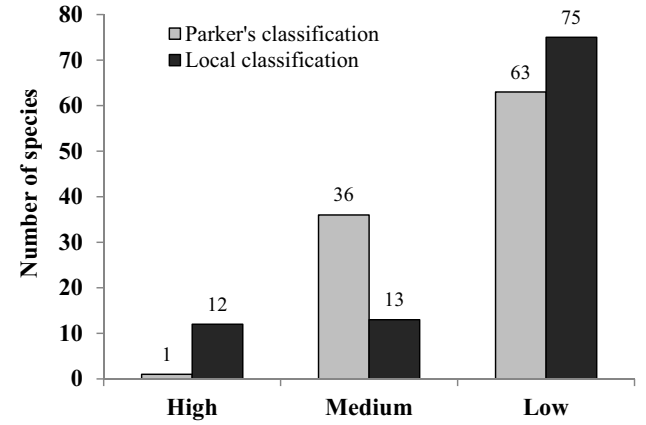

Fig. 2. Number of forest species classified at each sensitivity level using local classification and Parker's classification.

and four endemic species with significant restricted distribution in few patches (up to three patches). Also, five low-sensitivity species in Parker's classification (Capsiempis flaveola, Galbula ruficauda, Herpetotheres cachinnans, Patagioenas cayennensis and Tiaris fuliginosus) changed to medium-sensitivity in the local classification. Although they are not endemic, they showed a restricted distribution (up to five patches). Only one high-sensitivity species in Parker's classification (Habia rubica) decreased to low-sensitivity in our local classification (see Appendix G). This species is neither endemic nor threatened and was randomly distributed among the patches, as pointed by the ISA test $(F=0.047)$. Nineteen medium-sensitivity species in Parker's classification were changed to low-sensitivity in our local classification. These species were widely recorded in more than five patches, and even included some Atlantic forest endemic species (e.g., Automolus leucophthalmus, Conopophaga lineata and Synallaxis ruficapilla) (Appendix G).

Although most forest species (63\%) did not change their sensitivity level, we found that the changes to the other $37 \%$ did produce differences in the relationship between the forest species richness at each sensitivity level and the rank of ecosystem service provisioning. Analyzing each regression curve individually, the slopes for low and medium sensitivity for our local classification compared with low and high sensitivity for Parker's classification did not significantly differ from zero, indicating no relationship. Only the classifications provided by high local (slope $>0, \beta_{1}=0.3562$, $\mathrm{SE}=0.0689$ ), low local and low on Parker's classification (slope $=0$ ) and the medium on Parker's classification (slope $>0, \beta_{1}=0.0513$, $\mathrm{SE}=0.0173$ ) achieved our expected relationship with the ranking (Fig. 3, Table 3).

\subsection{Use of Parker's classification in environmental assessments}

Fifty percent (25) of all EAs we reviewed used Parker's classification in their bird inventories. These studies were carried out in different parts of São Paulo State from 2008 to 2013 (Appendices $\mathrm{D}$ and $\mathrm{E}$ ) encompassing different enterprises and types of infrastructure works, including industry and agribusiness activities (7); roads, highways, urban avenues (6); mining activities (3); landfill waste and sewage treatment plants (3); general industry, airport, pipeline gas, subway and urban trains, waterway, hydroelectric power plant and waste-to-energy power plant (one study each) (see Appendix D). All of these studies sampled forest patches. Nineteen studies (76\% of the studies that used Parker's classification) made conclusions about the forest environmental conditions based on the results of the sensitivity levels of the bird assemblages, thus using Parker's classification as an ecological indicator. Five studies could not support their conclusions about the forest environmental conditions using Parker's classification. Only one study used this parameter combined with other ecological and biological metrics (e.g., species frequency of occurrence, relative abundance, trophic guilds, threat status and endemism) to support the arguments about the forest conditions. Three studies disagreed with Parker's classification for some species. These ornithologists argued for long-term studies to understand the true impacts of the proposed activity on the bird assemblages. In addition, all the users reported high richness of low-sensitivity birds (ranging from $50 \%$ to $95 \%$ of the species recorded), followed by medium-sensitivity (ranging from $4 \%$ to $52 \%$ ) with few or complete absence of highsensitivity birds (ranging from $0 \%$ to $10 \%$ ) (see Appendix D).

\section{Discussion}

\subsection{Local sensitivity to disturbance}

Our results show that the level of sensitivity to forest habitat loss and fragmentation for forest species is not necessarily the same at continental (Neotropical) and local scales. Comparing our local classification with previous research that tested forest bird sensitivity to habitat loss and fragmentation effects in Atlantic Forest patches, we identified a lack of pattern of sensitivity for some species at local scales. For example, Habia rubica was considered a good bioindicator for large patches in the Rio de Janeiro State (Piratelli et al., 2008, approximately $650 \mathrm{~km}$ to the east of our study area) and vulnerable to local extinction in the Minas Gerais State (Ribon et al., 2003, approximately $670 \mathrm{~km}$ to the northeast of our study area). In addition, this species was highly sensitive to the simplification of the forest structure caused by fire in the Rio Doce State Park (LouresRibeiro et al., 2011, approximately $800 \mathrm{~km}$ to the northeast of our study area in the Minas Gerais State), one of the largest remnants of Interior Atlantic Forest. These studies could corroborate the high level of sensitivity assigned by Parker's classification. However, in the patches of northern Paraná State (approximately $500 \mathrm{~km}$ to the southwest of our study area) this species was considered to have low-sensitivity to forest fragmentation (Anjos, 2006), as we also observed. Another example is Penelope superciliaris, which is considered high-sensitivity in our study and critically endangered with local extinction by Ribon et al. (2003), but was considered to have low-sensitivity to the simplification of the forest structure in Loures-Ribeiro et al. (2011), while in Parker III et al. (1996) it is considered as medium-sensitivity.

One possible reason for this variation is the location of the study area. Species' populations on the edges of their geographical distributions may have higher sensitivity to forest fragmentation than those located in the center of the distribution (Anjos, 2006; Mendonça et al., 2009; Anjos et al., 2010). The recruitment of new individuals in populations of forest patches located on the geographical edge may be smaller as the distance to the species' center of distribution increases (Channell and Lomolino, 2000). Also, the landscape composition, configuration and history of fragmentation are factors that may exert selectivity on wild populations (Fahrig, 2003; Boscolo and Metzger, 2009; Metzger et al., 2009; Pardini et al., 2009; Prevedello and Vieira, 2010; Boscolo and Metzger, 2011; Lira et al., 2012; Martensen et al., 2012). Thus, each landscape context likely leads to distinct selective processes, and consequently favors different species (Watson et al., 2005; Nabe-Nielsen et al., 2010). Other factors of human action, such as hunting pressures and introduction of exotic species, may also contribute to bird local sensitivity (e.g., Thiollay, 2005; Alexandrino et al., 2012), although they were not tested yet. Another source of variation could be the lack of standardized ecological criteria chosen in the creation of each of the sensitivity levels in different studies. As already mentioned, Parker III et al. (1996) did not use clear criteria in their classification. Anjos (2006) and Loures-Ribeiro et al. (2011) considered only species occurrence at the sampled sites as a criterion to classify the species sensitivity. For example, while 

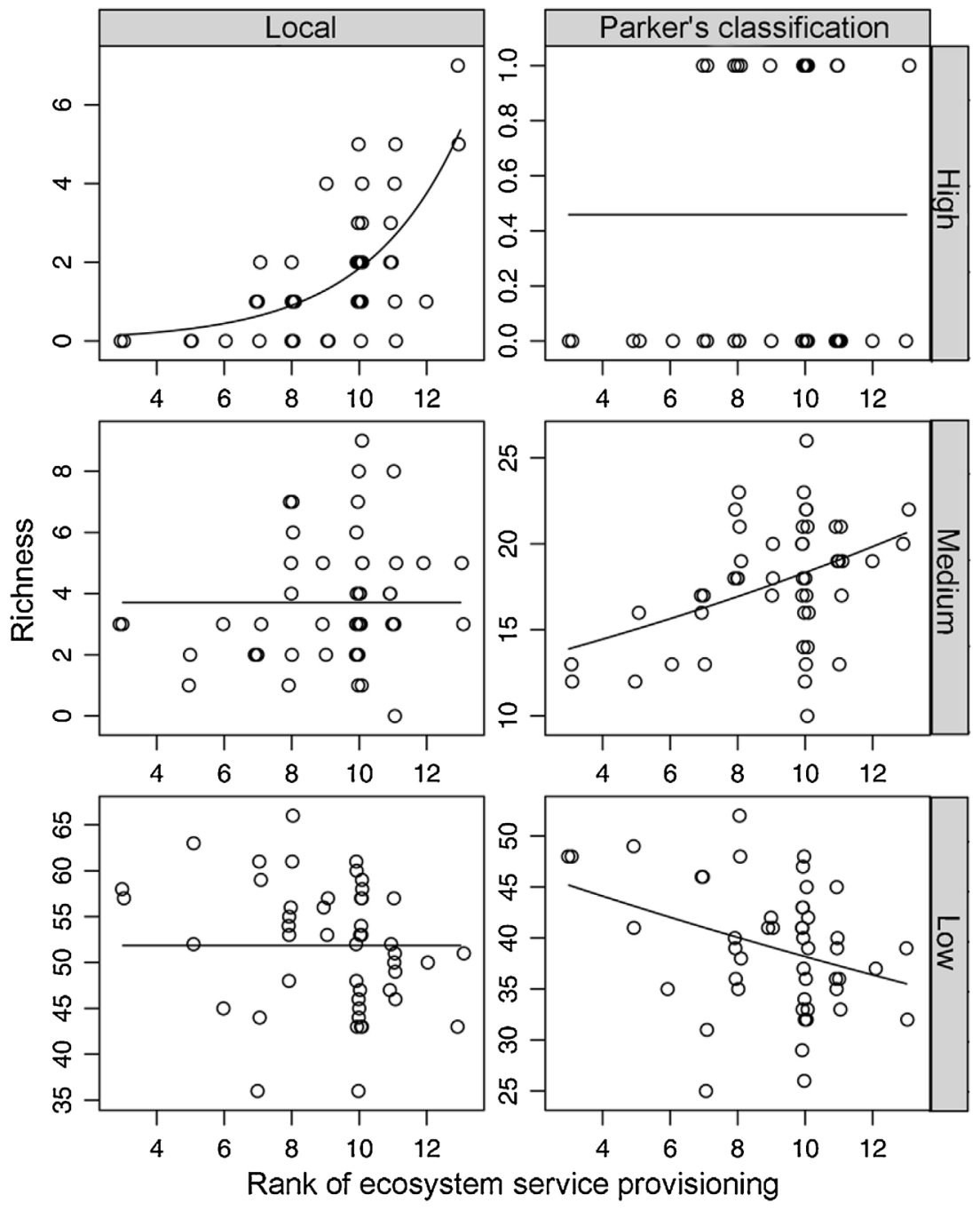

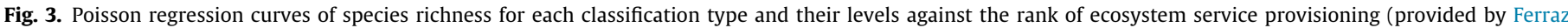

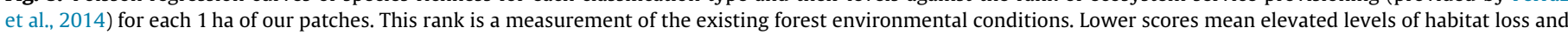
fragmentation while higher scores mean the opposite.

high-sensitivity species in Anjos (2006) were those with exclusive occurrence in larger and preserved patches ( 14 forest patches were studied), Loures-Ribeiro et al. (2011) assigned high-sensitivity to species that occurred only in the non-disturbed area in the Rio Doce State Park. In Piratelli et al. (2008), the species' relative abundance in the studied patches (six forest patches were studied) was considered to qualify them as bioindicators of forest fragmentation effects, but the species' occurrence in the largest patch also exerted high influence in the classifications, as done in Anjos (2006). In Ribon et al. (2003) the species' local extinction threat was assessed through the comparison of historical and recent records. However, in our study area there are no large and preserved patches nearby to use as "control patches" as Anjos (2006) and Piratelli et al. (2008) did, there are no available historical ornithological records and the forest patches have different history of degradation and re-growth (e.g., Ferraz et al., 2014), a complex situation. Thus, we necessarily considered other criteria to develop our three local levels of sensitivity, which was based on the knowledge provided by all these studies.

As the number of patches available to conduct our study was small (eight), we did not limited our classifications based only on bird occurrence and abundance. Data only from these patches are not enough to visualize at the present time the species' response to a prior process of fragmentation and habitat loss (e.g., Ewers
Table 3

The relationship between richness of each classification type and the rank of ecosystem service provisioning (provided by Ferraz et al., 2014) found in the studied patches. Results from likelihood-ratio tests for nested models to test whether the slope observed ( $\beta_{1}$ obs) did not differ statistically from 0 for each individual Poisson regression (Dev - Deviance, df - degrees of freedom, * indicate significance at $5 \%$ probability level). Slopes different from 0 mean that the respective level of sensitivity has a relationship with the rank of ecosystem service provisioning.

\begin{tabular}{|c|c|c|c|c|c|c|c|c|}
\hline & \multicolumn{4}{|l|}{ Local } & \multicolumn{4}{|c|}{ Parker's classification } \\
\hline & Dev & df & $p$ & $\beta 1$ obs & Dev & df & $p$ & $\beta 1$ obs \\
\hline High & 31.62 & 1 & $<0.001^{*}$ & $>0$ & 1.11 & 1 & 0.292 & $=0$ \\
\hline Medium & 2.75 & 1 & 0.097 & $=0$ & 9.13 & 1 & $0.003^{*}$ & $>0$ \\
\hline Low & 0.28 & 1 & 0.599 & $=0$ & 1.32 & 1 & 0.251 & $=0$ \\
\hline
\end{tabular}

and Didham, 2006), which started in our focal landscapes many years ago (see Ferraz et al., 2014). Thus, we considered the threat status and endemism as useful criteria to represent the historical species population responses to the fragmentation process. Threat species was considered high sensitivity because regional red list calls attention for the decreasing number of the species population and its regional distribution, and the future scenario of impacts (Gärdenfors et al., 2001; Bressan et al., 2009). Endemism was joined with occurrence and abundance field data because not all endemic birds are considered vulnerable to the fragmentation 
process (Brooks et al., 1999b, Anjos et al., 2010). However, we could not ignore that endemism was already shown as precursor to the local extinction threat (e.g., Ribon et al., 2003). Because of this we treated endemism as fewer critic characteristic in the classification process. These precautions diminished our subjectivity in weighting the three local sensitivity levels, a procedure that certainly contributed to generate different levels of sensitivity for some studied species.

Previous studies at local scales help to explain the differences in species richness for each sensitivity level. In Martensen et al. (2012), three Atlantic Forest landscapes of $108 \mathrm{~km}^{2}$ with different amounts of forest habitat were investigated. They found that the richness of Parker's high-sensitivity species increased in landscapes with $50 \%$ of forest habitat available (i.e., the best landscape studied). Similarly, in a landscape of $120 \mathrm{~km}^{2}$ with abundant forest habitat, Ribon et al. (2003) reported that Parker's high-sensitivity species (i.e., 18 species) have higher occurrences during a time when the human impacts were lower in the studied area. Because we studied smaller (five landscapes of $16 \mathrm{~km}^{2}$ ) and highly deforested (11\% forest cover) landscapes, and we observed only one high-sensitivity species according to Parker, we believe that higher richness of Parker's high-sensitivity species are primarily found in less deforested and impacted landscapes. Other studies performed in larger and protected Atlantic Forest patches also found elevated richness of high-sensitivity species, corroborating our assumption (e.g., more than 15 forest high-sensitivity species were reported in Develey and Martensen, 2006; Cavarzere et al., 2009; Antunes et al., 2013). This condition may explain the lack of relationship between Parker's high-sensitivity species and the variation of forest environmental conditions in more disturbed landscapes.

Species belonging to medium-sensitivity on Parker's classification tend to have intermediate richness levels between the high and low sensitivity species in forest patches of fragmented landscapes (e.g., Ribon et al., 2003; Franz et al., 2010; Arendt et al., 2012; Martensen et al., 2012). Even though we found the same result, we observed that the species we documented in this category encompass forest species very common in disturbed sites (e.g., Patagioenas picazuro, Tangara cayana, Brotogeris chiriri, Tolmomyias sulphurescens, Icterus pyrrhopterus), even urban zones (e.g., Franz et al., 2010; Cruz and Piratelli, 2011; Alexandrino et al., 2013), but also include some species naturally considered more vulnerable to habitat loss and fragmentation, such as endemic (e.g., Automolus leucophthalmus, Conopophaga lineata, Drymophila ferruginea, Mackenziaena severa) and near-threatened and threatened species (e.g., the near threatened species Amazona aestiva, Antilophia galeata, Campephilus robustus, Leptodon cayanensis and Penelope superciliaris, the vulnerable species Cyanoloxia brissonii, and the endangered species Lanio penicillatus). These last are mainly reported in large and preserved patches (e.g., Anjos, 2006; Develey and Martensen, 2006; Cavarzere et al., 2009; Antunes et al., 2013). Thus, we noticed that the existing relationship between the richness of Parker's medium-sensitivity level and our measurement of forest environmental conditions (i.e., the rank of ecosystem service provisioning from Ferraz et al., 2014) has occurred in our study area only by the presence of these listed species. In our local medium-sensitivity criterion, all threatened or endemic species (with limited distribution) considered medium-sensitivity in Parker's classification were classified as high-sensitivity, while those common species were classified as having low-sensitivity (Fig. 2, Appendix G). This resulted in a low richness value of species belonging to local medium-sensitivity, which did not correlate with the existing measurement of forest environmental conditions in the study area.

Meanwhile, the richness of species belonging to low-sensitivity was high in both classifications. The richness of Parker's lowsensitivity tends to be higher in HML (Willis and Oniki, 2002;
Pozza and Pires, 2003; Anjos, 2006; Franz et al., 2010; Arendt et al., 2012; Cruz and Piratelli, 2011; Alexandrino et al., 2013). Martensen et al. (2012) showed that the richness of this level was higher in a landscape with little forest habitat available (11\%), a similar environmental scenario as we studied. In addition, Ribon et al. (2003) showed that bird species of this sensitivity level have a small probability of local extinction in anthropogenic landscapes. These references suggest that these species will always be commonly observed in HML. However, our results indicate that even with a cautious local sensitivity classification, the richness of lowsensitivity species will not vary significantly along a gradient of environmental conditions in a HML. This is the same pattern seen with Parker's classification.

\subsection{Parker's classification as an ecological indicator}

Species and assemblages are part of the composition of an ecological system (Angermeier and Karr, 1994; Niemi and McDonald, 2004; Karr, 2006). An ecological indicator is considered valid if it is able to measure this composition in order to assess the condition of the environment or to diagnose the cause of an environmental change (Dale and Beyeler, 2001). Furthermore, a good ecological indicator is supposed to be highly sensitive to a particular stress, have a known response to disturbance or anthropogenic stress and be easily understood by the public (Dale and Beyeler, 2001; Niemi and McDonald, 2004). Although the richness of each Parker's classification level of sensitivity is easy to consult and theoretically simple to understand, we found that the effects of forest habitat loss and fragmentation represented through birds will only be demonstrated by Parker's classification if there are high-sensitivity species in the area under study. In this manner, Parker's classification would fulfill the ecological indicator assumption (at least for one level of the classification). However, our results suggest that Parker's classification could not be used as a forest habitat ecological indicator of patches in highly deforested landscapes, as most of the populations of Parker's high-sensitivity species likely disappeared from such sites years ago (e.g., Ribon et al., 2003). Besides, even though the richness of medium-sensitivity species by Parker's classification may show a viable number of species sufficient to run statistical tests on, the usage of a group of species that suffer slightly with human disturbances does not meet the ecological indicator assumption. As the sensitivity to fragmentation may be related to the location of the study area (Anjos, 2006; Anjos et al., 2010), it is not possible to ensure that Parker's medium-sensitivity reflects the effects of forest fragmentation in all landscapes. Also, the richness of low-sensitivity species cannot be used as an ecological indicator, as these species are not related to any specific forest environmental conditions.

Our results suggest that the safest way to assess existing forest habitat loss and fragmentation effects in a highly fragmented landscape using forest bird assemblages is to identify high-sensitivity species at the local scale (Fig. 3). This procedure was the only one that achieved the ecological indicator assumption (Dale and Beyeler, 2001; Carignan and Villard, 2002; Niemi and McDonald, 2004).

\subsection{The usage of Parker's classification}

Parker's classification was used in 50\% of the EAs we surveyed. Nonetheless, we found that the majority of the ornithologists that used Parker's classification used it as a reliable ecological indicator. Also, most do not account for the possibility of forest species having different sensitivity to disturbance at different scales of analysis, as very few studies have expressed concern or disagreement with Parker's classification. The users also seem unfamiliar with the existing recommendations in the book (Stotz et al., 1996): although 
the assumptions behind Parker's classification are not clear, Stotz et al. (1996) explain in the introduction of the book that this classification is mainly intended for researchers to pinpoint regions and habitats with threatened communities for conservation purposes. The authors urge users to devise their own analyses, tailoring them to local needs and local comparisons.

However, ornithologists that have used Parker's classification in EAs have tried to explain the richness found at each level in their study area using different arguments. Some have explained the lack of more high-sensitivity species in their study area by arguing that these species have naturally small populations, or because they are threatened and are hard to detect in limited field surveys. In the same way, all EAs considered that the presence of low-sensitivity species indicates a high degree of disturbance in the study area regardless of the scale of analysis. Some EAs assumed that the medium-sensitivity level was comparable to the high-sensitivity level to indicate environmental conditions, particularly when few high-sensitivity species were found in the study. These different explanations and treatments are proof that the lack of clear criteria used in Parker's classification allow for diverse interpretations, where often a variety of ecological concepts (i.e., rarity pattern, relative abundance, spatial distribution, detectability) are mixed together with subjective weights.

EIAs are one of the few internationally recognized and often legally embedded instruments to predict and minimize the potential consequences of human activities on the environment (Glasson and Salvador, 2000; Carroll and Turpin, 2002; Slootweg and Mollinga, 2010; Sánchez and Croal, 2012). Appropriate environmental organizations such as research institutions, universities, governmental departments and NGOs that monitor wildlife are encouraged to be consulted during the EAs, which may improve biodiversity assessments in the sites under investigation (Byron, 2000; Rajvanshi et al., 2010). However, in countries with few centers of ornithological research and a lack of available data from citizen science (e.g., Sullivan et al., 2014), environmental consultants may have little support to discuss their data in the time available for their EAs. Within the EIA process in Brazil, the enterprises have a mean of only a few months to conduct their EAs during the request for environmental licenses (Glasson and Salvador, 2000; CONAMA Resolution 001/86, CONAMA Resolution 237/1997, SMA Resolution 49/2014). This is a short period for bird sampling, analyses and final reporting (Vasconcelos, 2006; Silveira et al., 2010; Straube et al., 2010) which may force many ornithologists to use existing parameters that are easy to consult, as the Parker's classification, instead of adapting a more local metric. Also, considering that the environmental managers and policy makers ask for ecological indicators that are understood by the public (Schiller et al., 2001; Carignan and Villard, 2002; Niemi and McDonald, 2004), it makes sense that practitioners try to recognize the current condition of the ecosystems and predict the future for the wildlife and their habitat by resorting to simple and easily interpreted ecological parameters, such as Parker's classification.

Also, the ubiquitous usage of Parker's classification in academic studies in the Neotropics may be an additional reason for the continuing usage of this metric in EAs. Since its publication, this parameter has been used in many studies, as an untreated dependent variable, associated with other parameters to test the effects of fragmentation and landscape features in bird assemblages (e.g., Petit and Petit, 2003; Uezu et al., 2005; Barlow et al., 2006; Matlock Jr and Edwards 2006, Feeley et al., 2007; Hansbauer et al., 2008b; Lees and Peres, 2008; Martensen et al., 2008, 2012; Ferraz et al., 2012; Banks-Leite et al., 2013), as a parameter to support discussions about human disturbance effects on birds and habitat conditions (e.g., Woltmann, 2003; Oostra et al., 2008; Giacomo and Casenave, 2010; Lobo-Araújo et al., 2013) and to characterize the bird communities at a given site (e.g., Matlock Jr et al., 2002; Tejeda-Cruz and Sutherland, 2004; Franz et al., 2010; Arendt et al., 2012; Lyra-Neves et al., 2012). However, being the most used ecological indicator in the scientific literature does not mean that it is suitable for all types of environmental assessment (Dale and Beyeler, 2001; Carignan and Villard, 2002). Ignoring this fact in the EA may jeopardize the real interpretation of impacts that development could cause to wildlife and habitats (e.g., Thompson et al., 1997).

\subsection{Final considerations}

Our results highlight that different environmental conclusions can be made depending on the sensitivity classification used (local vs. Parker's classification). The richness of high-sensitivity species from Parker's classification could fail to predict the environmental conditions of patches at local scales of highly disturbed landscapes in the Neotropics. Therefore, taking into account that EAs are frequently conducted in landscapes with similar conditions to those of our study area (i.e., away from the largest patches of tropical forest, see Appendices D and E), we disagree that environmental analyses made under Parker's classification assumptions provide rigorous support for environmental decision-making in these HML. We suggest that future EAs in deforested landscapes avoid using Parker's classification as an ecological indicator.

Also, we must warn that our local sensitivity levels of forest species are not replicable for other similar landscapes or local scale analyses. Bird communities may have varying responses to habitat fragmentation in different landscapes (Watson et al., 2005; Anjos, 2006; Anjos et al., 2009, 2010). No matter the criteria used in each study to classify species' sensitivity status, it seems that there will always be a chance to find a species with different level than assigned in Parker's classification. Thus, we encourage professionals to explore local approaches that may reflect the local avifauna conditions to help assess the existing forest habitat loss and fragmentation effects on the patches. We showed that threat status, endemism, spatial distribution and relative abundance may be useful data.

As in many regions of the world, the Neotropics encompass countries with ongoing economic development where cities and rural areas are continuously growing (Ellis and Ramankutty, 2008; Seto et al., 2012), often into forested areas (Metzger et al., 2010; Wright, 2010; Verdade et al., 2012). EIA are an important mechanism for strategically planning this growth in an environmentally friendly fashion. However, our study warns about the necessity of continuous evaluation on the approaches used in the biodiversity assessment portion of the EA, in order to improve the quality of assessments. In a time when there is growing interest in the potential ecosystem services provided by tropical forest patches in anthropogenic landscapes around the world (e.g., Uezu et al., 2008; Tabarelli et al., 2010; Muñoz et al., 2013; Melo et al., 2013; Ferraz et al., 2014), it is necessary that consultants, environmental decision makers, and field biologists ensure that their approaches are useful in supporting their decisions (Walsh et al., 2014). Otherwise, erroneous predictions of the ecological impacts of proposed infrastructure works will continue to be common worldwide, putting the objectives of EIA at risk (e.g., Thompson et al., 1997).

\section{Acknowledgements}

We are grateful to the Forest Science Department and "Luiz de Queiroz" College of Agriculture (Brazil) and the Department of Biology, University of Utah (USA), where this research was performed. We also thank all of the landowners who allowed us access to the forest patches in their property. We thank Alexandre C. Franchin, Luiz dos Anjos and Carlos Candia-Gallardo by the fruitful discussions, as well as the paper reviewers. This research was funded by 
FAPESP (Processes 2010/05343-5, 2011/06782-5, 2014/14925-9) and made during the first author's PhD in Applied Ecology (Programa de Pós-graduação Interunidades em Ecologia Aplicada Universidade de São Paulo. Escola Superior de Agricultura "Luiz de Queiroz"). We thank CNPq for the productivity fellowship (grant \#308503/2014-7) granted to K.M.P.M.B. Ferraz.

\section{Appendix A. Supplementary data}

Supplementary data associated with this article can be found, in the online version, at http://dx.doi.org/10.1016/j.ecolind.2016. 02.006.

\section{References}

Alexandrino, E.R., Luz, D.T.A.D., Maggiorini, E.V., Ferraz, K.M.P.M.D., 2012. Nest stolen: the first observation of nest predation by an invasive exotic marmoset (Callithrix penicillata) in an agricultural mosaic. Biota Neotrop. 12 (2), 211-215.

Alexandrino, E.R., Bovo, A.A.A., Luz, D.T.A., Costa, J.C., Betini, G.S., Ferraz, K.M.P.M.B. Couto, H.T.Z., 2013. Aves do campus Luiz de Queiroz (Piracicaba/SP) da Universidade de São Paulo: mais de 10 anos de observações neste ambiente antrópico. Atualidades Ornitol. 173, 40L 52.

Angermeier, P.L., Karr, J.R., 1994. Biological integrity versus biological diversity as policy directives. BioScience 44 (10), 690-697.

Anjos, L., Boçon, R., 1999. Bird communities in natural forest patches in southern Brazil. Wilson Bull. 111, 397-414.

Anjos, L., Zanette, L., Lopes, E.V., 2004. Effects of fragmentation on the bird guilds of the Atlantic Forest in North Paraná, Southern Brazil. Ornitol. Neotrop. 15 (Suppl.), $137-144$

Anjos, L., 2006. Bird species sensitivity in a fragmented landscape of the Atlantic forest in southern Brazil. Biotropica 38, 229L 234

Anjos, L., Bochio, G.M., Silva, J.V.C.E., McCrate, G., 2009. Sobre o uso de níveis de sensibilidade de aves à fragmentação florestal na Avaliação da Integridade Biótica: um estudo de caso no norte do Estado do Paraná, sul do Brasil. Rev. Bras. Ornitol $17,28-36$

Anjos, L., Holt, R., Robinson, S., 2010. Position in the distributional range and sensitivity to forest fragmentation in birds: a case history from the Atlantic forest Brazil. Bird Conserv. Int. 20, 392-399.

Anjos, L., Collins, C.D., Holt, R.D., Volpato, G.H., Mendonça, L.B., Lopes, E.V., Boçon, R., Bisheimer, M.V., Serafini, P.P., Carvalho, J., 2011. Bird species abundance occupancy patterns and sensitivity to forest fragmentation: implications for conservation in the Brazilian Atlantic forest. Biol. Conserv. 144, 2213-2222.

Antunes, A.Z., Silva, B.G., Matsukuma, C.K., Eston, M.R., Santos, A.M.R., 2013. Birds from Carlos Botelho Park state of São Paulo southeastern Brazil. Biota Neotrop. 13 (2), 124-140.

Arendt, W.J., Tórrez, M., Vílchez, S., 2012. Diversidad de aves en agropaisajes en la region norte de Nicaragua. Ornitol. Neotrop. 23, 113-131.

Awade, M., Metzger, J.P., 2008. Using gap-crossing capacity to evaluate functional connectivity of two Atlantic rainforest birds and their response to fragmentation. Austral Ecol. 33, 863-871.

Banks-Leite, C., Ewers, R.M., Metzger, J.P., 2010. Edge effects as the principal cause of area effects on birds in fragmented secondary forest. Oikos 119, 918-926.

Banks-Leite, C., Ewers, R.M., Kapos, V., Martensen, A.C., Metzger, J.P., 2011. Comparing species and measures of landscape structure as indicators of conservation importance. J. Appl. Ecol. 48, 706L 714.

Banks-Leite, C., Ewers, R.M., Metzger, J.P., 2013. The confounded effects of habitat disturbance at the local, patch and landscape scale on understorey birds of the Atlantic Forest: implications for the development of landscape-based indicators. Ecol. Indic. 31, 82-88

Barlow, J., Peres, C.A., Henriques, L.M.P., Stouffer, P.C., Wunderle, J.M., 2006. The responses of understorey birds to forest fragmentation, logging and wildfires: an Amazonian synthesis. Biol. Conserv. 128 (2), 182-192.

Bencke, G.A., Mauricio, G.N., Develey, P.F., Goerck, J.M., 2006. Áreas importantes para a conservação das aves no Brasil: parte 1, estados do domínio da Mata Atlântica. SAVE ed., São Paulo, Brasil, 494 pp.

Bibby, C.J., Burgess, N.D., Hill, D.A., Mustoe, S.H., 2000. Bird Census Techniques, 2nd edition. Academic Press Limited, San Diego, 302 pp.

Boscolo, D., Candia-Gallardo, C., Awade, M., Metzger, J.P., 2008. Importance of interhabitat gaps and stepping-stones for Lesser Woodcreepers (Xiphorhynchus fuscus) in the Atlantic Forest, Brazil. Biotropica 40 (3), 273-276.

Boscolo, D., Metzger, J.P., 2009. Is bird incidence in Atlantic forest fragments influenced by landscape patterns at multiple scales? Landsc. Ecol. 24 (7), 907-918

Boscolo, D., Metzger, J.P., 2011. Isolation determines patterns of species presence in highly fragmented landscapes. Ecography 34, 1-12.

Bradford, D.F., Franson, S.E., Neale, A.C., Heggem, D.T., Miller, G.R., Canterbury, G.E., 1998. Bird species assemblages as indicators of biological integrity in Great Basin rangeland. Environ. Monit. Assess. 49, 1-22.

Bressan, P.M., Kierulff, M.C.M., Sugieda, A.M., 2009. Fauna ameaçada de extinção no Estado de São Paulo. Fundação Parque Zoológico de São Paulo: Secretaria do Meio Ambiente, São Paulo.
Brito, D., Ambal, R.G., Brooks, T., De Silva, N., Foster, M., Hao, W., Hilton-Taylor, C., Paglia, A., Rodríguez, J.P., Rodríguez, J.C., 2010. How similar are national red lists and the IUCN Red List? Biol. Conserv. 143, 1154-1158.

Brooks, T.M., Pimm, S.L., Oyugi, J.O., 1999a. Time lag between deforestation and bird extinction in tropical forest fragments. Conserv. Biol. 13 (5), 1140-1150.

Brooks, T., Tobias, J., Balmford, A., 1999b. Deforestation and bird extinctions in the Atlantic forest. Anim. Conserv. 2 (3), 211-222.

Byron, H., 2000. Biodiversity and Environmental Impact Assessment: A Good Practice Guide for Road Schemes. The RSPB, WWF-UK, English Nature and the Wildlife Trusts, Sandy.

Candido Jr., J.F., 2000. The edge effects in a forest bird community in Rio Claro, São Paulo State, Brazil. Rev. Bras. Ornitol. 8 (1), 9-16.

Canterbury, G.E., Martin, T.E., Petit, D.R., Petit, L.J., Bradford, D.F., 2000. Bird communities and habitat as ecological indicators of forest condition in regional monitoring. Conserv. Biol. 14, 544-558.

Carignan, V., Villard, M.A., 2002. Selecting indicator species to monitor ecological integrity: a review. Environ. Monit. Assess. 78 (1), 45-61.

Carroll, B., Turpin, T., 2002. Environmental Impact Assessment Handbook: A Practical Guide for Planners, Developers and Communities. Thomas Telford, $177 \mathrm{pp}$.

Cavarzere, V., Moraes, G.P., Donatelli, R.J., 2009. Avifauna da Estação Ecológica dos Caetetus, interior de São Paulo, Brasil. Papéis Avulsos Zool. 49 (35), 477-485.

Cavarzere, V., Moraes, G.P., Dalbeto, A.C., Maciel, F.D.G., Donatelli, R.J., 2011. Birds from cerradão woodland, an overlooked forest of the Cerrado region, Brazil. Papéis Avulsos Zool. 51 (17), 259-274.

Chang, T., Nielsen, E., Auberle, W., Solop, F.I., 2013. A quantitative method to analyze the quality of EIA information in wind energy development and avian/bat assessments. Environ. Impact Assess. Rev. 38, 142-150.

Chambers, S.A., 2008. Birds as Environmental Indicators: Review of Literature. Parks Victoria Technical Series No. 55. Parks Victoria, Melbourne.

Channell, R., Lomolino, M.V., 2000. Dynamic biogeography and conservation of endangered species. Nature 403, 84-86.

Chazdon, R.L., Letcher, S.G., Breugel, M.V., Martínez-Ramos, M., Bongers, F., Finegan, B., 2007. Rates of change in tree communities of secondary Neotropical forests following major disturbances. Philos. Trans. R. Soc. B 362, 273-289.

Comitê Brasileiro de Registros Ornitológicos, 2014. Listas das aves do Brasil, $11^{a}$ Edição. www.cbro.org.br/CBRO/index.htm (accessed 18.07.14).

CONAMA Resolution 001/86. Available in: http://www.mma.gov.br/port/conama/ res/res86/res0186.html (accessed 20.08.14).

CONAMA Resolution 237/1997. Available in: http://www.mma.gov.br/port conama/res/res97/res23797.html (accessed 20.08.14).

Cruz, B.B., Piratelli, A.J., 2011. Avifauna associated to an urban extend of the Sorocaba River, Southeastern Brazil. Biota Neotrop. 11 (4), 255-264.

Dale, V.H., Beyeler, S.C., 2001. Challenges in the development and use of ecological indicators. Ecol. Indic. 1, 3-10.

Demétrio, C.G.B., Hinde, J., Moral, R.A., 2014. Models for overdispersed data in entomology. In: Ferreira, C.P., Godoy, W.A.C. (Eds.), Ecological Modelling Applied to Entomology. Springer.

Develey, P.F., Martensen, A.C., 2006. Birds of Morro Grande Reserve (Cotia SP). Biota Neotrop. 6 (2) http://www.biotaneotropica.org.br/v6n2/pt/ abstract?article+bn00706022006.

DeWalt, S.R., Maliakal, S.K., Denslow, J.S., 2003. Changes in vegetation structure and composition along a tropical forest chronosequence: implications for wildlife. For. Ecol. Manage. 182, 139L 151.

Dufrêne, M., Legendre, P., 1997. Species assemblages and indicator species: the need for a flexible asymmetrical approach. Ecol. Monogr. 67 (3), 345-366.

Durães, R., Carrasco, L., Smith, T.B., Karubian, J., 2013. Effects of forest disturbance and habitat loss on avian communities in a Neotropical biodiversity hotspot. Biol. Conserv. 166, 203-211.

Ellis, E.C., Ramankutty, N., 2008. Putting people in the map: anthropogenic biomes of the world. Front. Ecol. Environ. 6 (8), 439-447.

Ewers, R.M., Didham, R.K., 2006. Confounding factors in the detection of species responses to habitat fragmentation. Biol. Rev. 81 (1), 117-142.

Fahrig, L., 2003. Effects of habitat fragmentation on biodiversity. Annu. Rev. Ecol. Evol. Syst. 34, 487-515.

Feeley, K.J., Gillespie, T.W., Lebbin, D.J., Walter, H.S., 2007. Species characteristics associated with extinction vulnerability and nestedness rankings of birds in tropical forest fragments. Anim. Conserv. 10 (4), 493-501.

Ferraz, K.M.P.M.B., Siqueira, M.F., Alexandrino, E.R., Luz, D.T.A., Couto, H.T.Z., 2012. Environmental suitability of a highly fragmented and heterogeneous landscape for forest bird species in southeastern Brazil. Environ. Conserv. 39 (4) 316-324.

Ferraz, S.F.B., Ferraz, K.M.P.M.B., Cassiano, C.C., Brancalion, P.H., Luz, D.T.A., Azevedo, T.N., Tambosi, L., Metzger, J.P., 2014. How good are tropical forest patches for ecosystem services provisioning? Landsc. Ecol. 29 (2), 187-200.

Foley, J.A., DeFries, R., Asner, G.P., Barford, C., Bonan, G., Carpenter, S.R., Chapin, F.S., Coe, M.T., Daily, G.C., Gibbs, H.K., Helkowski, J.H., Holloway, T., Howard, E.A. Kucharik, C.J., Monfreda, C., Patz, J.A., Prentice, I.C., Ramankutty, N., Snyder, P.K., 2005. Global consequences of land use. Science 309, 570L 574.

Franz, I., Cappelatti, L., Barros, M.P., 2010. Bird community in a forest patch isolated by the urban matrix at the Sinos River basin, Rio Grande do Sul State, Brazil, with comments on the possible local defaunation. Braz. J. Biol. 70 (4 (Suppl.)), 1137-1148.

Gardner, T.A., Barlow, J., Araujo, I.S., Ávila-Pires, T.C., Bonaldo, A.B., Costa, J.E., Esposito, M.C., Ferreira, L.V., Hawes, J., Hernandez, M.I.M., Hoogmoed, M.S., Leite, R.N., Lo-Man-Hung, N.F., Malcolm, J.R., Martins, M.B.L., Mestre, A.M., MirandaSantos, R., Overal, W.L., Parry, L., Peters, S.L., Ribeiro-Junior, M.A., da Silva, M.N.F., 
da Silva Motta, C., Peres, C.A., 2008. The cost-effectiveness of biodiversity surveys in tropical forests. Ecol. Lett. 11 (2), 139-150.

Gärdenfors, U., Hilton-Taylor, C., Mace, G.M., Rodríguez, J.P., 2001. The application of IUCN Red list criteria at regional levels. Conserv. Biol. 15, 1206-1212.

Giacomo, A.S.D., Casenave, J.L.D., 2010. Use and importance of crop and fieldmargin habitats for birds in a neotropical agricultural ecosystem. Condor 112 (2), 283-293.

Glasson, J., Salvador, N.N.B., 2000. EIA in Brazil: a procedures - practice gap. A comparative study with reference to the European Union, and especially the UK. Environ. Impact Assess. Rev. 20, 191-225.

Goerck, J.M., 1997. Patterns of rarity in the birds of the Atlantic forest of Brazil. Conserv. Biol. 11 (1), 112-118.

Hansbauer, M.M., Storch, I., Leu, S., Nieto-Holguin, J-P., Pimentel, R.G., Knauer, F., Metzger, J.P., 2008a. Movements of neotropical understory passerines affected by anthropogenic forest edges in the Brazilian Atlantic rainforest. Biol. Conserv. $141,782-791$.

Hansbauer, M.M., Storch, I., Pimentel, R.G., Metzger, J.P., 2008b. Comparative range use by three Atlantic Forest understorey bird species in relation to forest fragmentation. J. Trop. Ecol. 24 (3), 291-299.

Henle, K., Davies, K.F., Kleyer, M., Margules, C., Settele, J., 2004. Predictors of species sensitivity to fragmentation. Biodivers. Conserv. 13 (1), 207-251.

Hockey, P.A.R., Curtis, O.E., 2009. Use of basic biological information for rapid prediction of the response of species to habitat loss. Conserv. Biol. 23 (1), 64-71.

Karr, J.R., 2006. Seven foundations of biological monitoring and assessment. Biol. Ambient. 20 (2), 7-18.

Kolhoff, A., Schijf, B., Verheem, R., Slootweg, R., 2010. Environmental assessment. In: Slootweg, R., Rajvanshi, A., Mathur, V.B., Kolhoff, A. (Eds.), Biodiversity in Environmental Assessment: Enhancing Ecosystem Services for Human WellBeing. Cambridge University Press.

Kronka, F.J.N., Nalon, M.A., Matsukuma, C.K., Kanashiro, M.M., Ywane, M.S.S., Pavão, M., Durigan, G., Lima, L.M.P.R., Guillaumon, J.R., Baitello, J.B., Borgo, S.C., Manetti, L.A., Barradas, A.M.F., Fukuda, J.C., Shida, C.N., Monteiro, C.H.B., Pontinha, A.A.S., Andrade, G.G., Barbosa, O., Soares, A.P., 2005. Inventário florestal da vegetação natural do estado de São Paulo. Secretaria do Meio Ambiente, Instituto Florestal, Imprensa Oficial, São Paulo, 200 pp.

IBAMA Normative Instruction n.146/2007. Available in: http://www.icmbio.gov.br/ sisbio/images/stories/instrucoes_normativas/IN146_2007_Empreendimentos. pdf (accessed 20.08.14).

IBGE, 2015. Diretoria de Pesquisas, Coordenação de População e Indicadores Sociais. Stats of Rio Claro - available in: http://cod.ibge.gov.br/8Q86. Stats of Charqueada - available in: http://cod.ibge.gov.br/71NV (accessed 15.02.15).

Laurance, W.F., Lovejoy, T.E., Vasconcelos, H.L., Bruna, E.M., Didham, R.K., Stouffer, P.C., Gascon, C., Bierregaard, R.O., Laurance, S.G., Sampaio, E., 2002. Ecosystem decay of Amazonian forest fragments: a 22-year investigation. Conserv. Biol. 16 (3), 605-618.

Lees, A.C., Peres, C.A., 2008. Avian life-history determinants of local extinction risk in a hyper-fragmented neotropical forest landscape. Anim. Conserv. 11 (2), $128-137$.

Lima, L.M., (Master's dissertation) 2013. Aves da Mata Atlântica: riqueza, composição, status, endemismos e conservação. Instituto de Biociências, University of São Paulo, São Paulo, Brazil, Available in: http://www.teses.usp.br/ teses/disponiveis/41/41133/tde-17042014-091547 (accessed 30.09.14).

Lira, P.K., Ewers, R.M., Banks-Leite, C., Pardini, R., Metzger, J.P., 2012. Evaluating the legacy of landscape history: extinction debt and species credit in bird and small mammal assemblages in the Brazilian Atlantic Forest. J. Appl. Ecol. 49, 1325L 1333.

Lobo-Araújo, L.W., Toledo, M.T., Efe, M.A., Malhado, A., Vital, M.V., Toledo-Lima, G.S., Macario, P., Santos, J.G., Ladle, R.J., 2013. Bird communities in three forest types in the Pernambuco Centre of Endemism, Alagoas, Brazil. Iheringia Sér. Zool. 103 (2), 85-96.

Loures-Ribeiro, A., Manhães, M.A., Dias, M.M., 2011. Sensitivity of understorey bird species in two different successional stages of the lowland Atlantic Forest, Brazil. Anais Acad. Bras. Ciênc. 83 (3), 973-980.

Lyra-Neves, R.M., Telino Jr., W.R., Larraz, M.E.L., 2012. The birds of the Talhado do São Francisco natural monument in the semi-arid Brazilian northeast. Rev. Bras. Ornitol. 20 (3), 268-289.

Manu, S., Peach, W., Cresswell, W., 2007. The effects of edge, fragment size and degree of isolation on avian species richness in highly fragmented forest in West Africa. Ibis 149, 287-297.

Marini, M.A., 2010. Bird movement in a fragmented Atlantic Forest landscape. Stud. Neotrop. Fauna Environ. 45 (1), 1-10

Martensen, A.C., Pimentel, R.G., Metzger, J.P., 2008. Relative effects of fragment size and connectivity on bird community in the Atlantic Rain Forest: implications for conservation. Biol. Conserv. 141 (9), 2184-2192.

Martensen, A.C., Ribeiro, M.C., Banks-Leite, C., Prado, P.I., Metzger, J.P., 2012. Associations of forest cover, fragment area, and connectivity with neotropical understory bird species richness and abundance. Conserv. Biol. 26 (6), 1100-1011.

Martin, P.A., Newton, A.C., Bullock, J.N., 2013. Carbon pools recover more quickly than plant biodiversity in tropical secondary forests. Proc. R. Soc. B: Biol. Sci. 280 (1773), 1-8.

Matlock Jr., R.B., Rogers, D., Edwards, P.J., Martin, S.G., 2002. Avian communities in forest fragments and reforestation areas associated with banana plantations in Costa Rica. Agric. Ecosyst. Environ. 91 (1), 199-215.

Matlock Jr., R.B., Edwards, P.J., 2006. The influence of habitat variables on bird communities in forest remnants in Costa Rica. Biodivers. Conserv. 15 (9), 2987-3016.
McCullagh, P., Nelder, J.A., 1989. Generalized Linear Models. Chapman and Hall London.

McCune, B., Mefford, M.J., 1997. PC-ORD. Multivariate Analysis of Ecological Data. MJM Software Design, Gleneden Beach, OR.

Melo, F.P., Arroyo-Rodríguez, V., Fahrig, L., Martinez-Ramos, M., Tabarelli, M., 2013. On the hope for biodiversity-friendly tropical landscapes. Trends Ecol. Evol. 28 (8), 462-468.

Mendonça, L.B., Lopes, E.V., Anjos, L., 2009. On the possible extinction of birc species in the Upper Paraná River floodplain, Brazil. Braz. J. Biol. 69 (2 (Suppl.)), 747-755.

Metzger, J.P., Martensen, A.C., Dixo, M., Bernacci, L.C., Ribeiro, M.C., Teixeira, A.M.G. Pardini, R., 2009. Time-lag in biological responses to landscape changes in a highly dynamic Atlantic forest region. Biol. Conserv. 142 (6), 1166-1177.

Metzger, J.P., Lewinsohn, T.M., Joly, C.A., Verdade, L.M., Martinelli, L.A., Rodrigues, R.R., 2010. Brazilian law: full speed in reverse? Science 329, 276-277.

Milner-Gulland, E.J., Kreuzberg-Mukhina, E., Grebot, B., Ling, S., Bykova, E. Abdusalamov, I., Bekenov, A., Gärdenfors, U., Hilton-Taylor, C., Salnikov, V., Stogova, L., 2006. Application of IUCN red listing criteria at the regiona and national levels: a case study from Central Asia. Biodivers. Conserv. 15 1873-1886.

Modena, E.S., Rodrigues, M., Souza, A.L.T., 2013. Trophic structure and composition of an understory bird community in a succession gradient of Brazilian Atlantic forest. Ornithologia 6 (1), 78-88.

Motta-Junior, J.C., Granzinolli, M.A.M., Develey, P.F., 2008. Birds of the Estação Ecológica de Itirapina, State of São Paulo, Brazil. Biota Neotrop. 8 (3), 207-227.

Muñoz, J.C., Aerts, R., Thijs, K.W., Stevenson, P.R., Muys, B., Sekercioglu, C.H. 2013. Contribution of woody habitat islands to the conservation of birds and their potential ecosystem services in an extensive Colombian rangeland. Agric. Ecosyst. Environ. 173, 13-19.

Nabe-Nielsen, J., Sibly, R.M., Forchhammer, M.C., Forbes, V.E., Topping, C.J., 2010 The effects of landscape modifications on the long-term persistence of animal populations. PLoS ONE 5 (1), e8932, http://dx.doi.org/10.1371/journal.pone. 0008932.

Niemi, G.J., McDonald, M.E., 2004. Application of ecological indicators. Annu. Rev. Ecol. Evol. Syst. 35, 89-111, http://dx.doi.org/10.1146/annurev.ecolsys.35. 112202.130132.

Oostra, V., Gomes, L.G., Nijman, V., 2008. Implications of deforestation for the abundance of restricted-range bird species in a Costa Rican cloud-forest. Bird Conserv. Int. 18 (1), 11-19.

Pardini, R., Faria, D., Accacio, G.M., Laps, R.R., Mariano-Neto, E., Paciencia, M.L.B. Dixo, M., Baumgarten, J., 2009. The challenge of maintaining Atlantic forest biodiversity: a multi-taxa conservation assessment of specialist and generalist species in an agro-forestry mosaic in southern Bahia. Biol. Conserv. 142 (7), $1178-1190$

Parker III, T.A., Stotz, D.F., Fitzpatrick, J.W., 1996. Ecological and distributiona databases. In: Stotz, D.F., Fitzpatrick, J.W., Parker III, T.A., Moskovits, D.K. (Eds.), Neotropical Birds: Ecology and Conservation. The University of Chicago Press Chicago, pp. 111-410.

Petit, L.J., Petit, D.R., 2003. Evaluating the importance of human-modified lands for neotropical bird conservation. Conserv. Biol. 17 (3), 687-694.

Piratelli, A., Sousa, S.D., Corrêa, J.S., Andrade, V.A., Ribeiro, R.Y., Avelar, L.H., Oliveira, E.F., 2008. Searching for bioindicators of forest fragmentation: passerine birds in the Atlantic forest of southeastern Brazil. Braz. J. Biol. 68 (2), 259-268.

Pozza, D.D., Pires, J.S.R., 2003. Bird communities in two fragments of semideciduous forest in rural São Paulo state. Braz. J. Biol. 63 (2), 307-319.

Prevedello, J.A., Vieira, M.V., 2010. Does the type of matrix matter? A quantitative review of the evidence. Biodivers. Conserv. 19, 1205-1223.

Rajvanshi, A., Mathur, V.B., Slootweg, R., 2010. Biodiversity in environmental impact ssessment. In: Slootweg, R., Rajvanshi, A., Mathur, V.B., Kolhoff, A. (Eds.), Biodiversity in Environmental Assessment: Enhancing Ecosystem Services for Human Well-Being. Cambridge University Press.

R Development Core Team, 2014. R: A Language and Environment for Statistical Computing. R Foundation for Statistical Computing, Vienna, Austria http://www. R-project.org.

Ribeiro, M.C., Metzger, J.P., Martensen, A.C., Ponzoni, F.J., Hirota, M.M., 2009. The Brazilian Atlantic Forest: how much is left, and how is the remaining forest distributed? Implications for conservation. Biol. Conserv. 142, 1141-1153.

Ribon, R., Simon, J.E., Mattos, G.T., 2003. Bird extinctions in Atlantic forest fragments of the Viçosa region, southeastern Brazil. Conserv. Biol. 17, 1827-1839.

Sánchez, L.E., Silvia-Sánchez, S.S., 2008. Tiering strategic environmental assessment and project environmental impact assessment in highway planning in São Paulo, Brazil. Environ. Impact Assess. Rev. 28 (7), 515-522.

Sánchez, L.E., Croal, P., 2012. Environmental impact assessment, from Rio-92 to Rio+20 and beyond. Ambiente Soc. 15 (3), 41-54.

Schiller, A., Hunsaker, C.T., Kane, M.A., Wolfe, A.K., Dale, V.H., Suter, G.W., Russell, C.S. Pion, G., Jensen, M.H., Konar, V.C., 2001. Communicating ecological indicators to decision makers and the public. Conserv. Ecol. 5 (1), 19.

Sekercioglu, C.H., 2006. Increasing awareness of avian ecological function. Trends Ecol. Evol. 21 (8), 464-471.

Sekercioglu, C.H., 2012. Bird functional diversity and ecosystem services in tropical forests, agroforests and agricultural areas. J. Ornithol. 153, 153-161.

Seto, K.C., Güneralp, B., Hutyra, L.R., 2012. Global forecasts of urban expansion to 2030 and direct impacts on biodiversity and carbon pools. Proc. Natl. Acad. Sci. 109 (40), 16083-16088.

Silva, J.M.C., Bates, J.M., 2002. Biogeographic patterns and conservation in the South American Cerrado: a tropical savanna hotspot. BioScience 52 (3), 225-233. 
Silva, J.M.C., Casteleti, C.H.M., 2003. Status of the biodiversity of the Atlantic forest of Brazil. In: Galindo-Leal, C., Câmara, I.G. (Eds.), State of the Hotspots: The Atlantic Forest of South America: Biodiversity Status, Threats, and Outlook. Island Press, Washington, pp. 43-59.

Silva, J.M.C., Sousa, M.C., Casteleti, C.H.M., 2004. Areas of endemism for passerine birds in the Atlantic forest, South America. Global Ecol. Biogeogr. 13, 85-92.

Silveira, L.F., Benedicto, G.A., Schunck, F., Sugieda, A.M., 2009. Aves. In: Bressan, P.M., Kierulff, M.C.M., Sugieda, A.M. (Eds.), Fauna ameaçada de extinção no Estado de São Paulo. Fundação Parque Zoológico de São Paulo: Secretaria do Meio Ambiente, São Paulo.

Silveira, L.F., Beisiegel, B.M., Curcio, F.F., Valdujo, P.H., Dixo, M., Verdade, V.K., Mattox, G.M.T., Cunningham, P.T.M., 2010. What use do fauna inventories serve? Estudos Avançados 24 (68), 173-207.

Slootweg, R., Mollinga, P.P., 2010. The impact assessment framework. In: Slootweg, R., Rajvanshi, A., Mathur, V.B., Kolhoff, A. (Eds.), Biodiversity in Environmental Assessment: Enhancing Ecosystem Services for Human Well-Being. Cambridge University Press.

SMA Resolution 49/2014. Available in: http://www.ambiente.sp.gov.br/legislacao/ files/2014/05/RESOLUCAO-SMA-49-28052014.pdf (accessed 20.08.14).

Stouffer, P.C., Strong, C., Naka, L.N., 2009. Twenty years of understorey bird extinctions from Amazonian rain forest fragments: consistent trends and landscape-mediated dynamics. Divers. Distrib. 15, 88-97.

Stotz, D.F., Fitzpatrick, J.W., Parker III, T.A., Moskovits, D.K., 1996. Neotropical Birds. Ecology and Conservation. The University of Chicago Press, Chicago, 478 pp.

Stratford, J.A., Stouffer, P.C., 1999. Local extinctions of terrestrial insectivorous birds in a fragmented landscape near Manaus, Brazil. Conserv. Biol. 13, 1416-1423.

Straube, F.C., Vasconcelos, M.F., Urben-Filho, A., Cândido-Jr., J.F., 2010. Protocolo mínimo para levantamentos de avifuna em estudos de impacto ambiental. In: Matter, S.V., Straube, F.C., Accordi, I., Piacentini, V., Cândido-Jr., J.F. (Eds.), Ornitologia e Conservação. Ciência Aplicada, Técnicas de pesquisa e Levantamento. Technical Books, Rio de Janeiro, pp. 237-254.

Sullivan, B.L., Aycrigg, J.L., Barry, J.H., Bonney, R.E., Bruns, N., Cooper, C.B., Damoulas, T., Dhondt, A.A., Dietterich, T., Farnsworth, A., Fink, D., Fitzpatrick, J.W., Fredericks, T., Gerbracht, J., Gomes, C., Hochachka, W.M., Iliff, M.J., Lagoze, C., La Sorte, F.A., Merrifield, M., Morris, W., Phillips, T.B., Reynolds, M., Rodewald, A.D., Rosenberg, K.V., Trautmann, N.M., Wiggins, A., Winkler, D.W., Wong, W.K., Wood, C.L., Yu, J., Kelling, S., 2014. The eBird enterprise: an integrated approach to development and application of citizen science. Biol. Conserv. 169, 31-40.

Sutherland, W.J., Newton, I., Green, R.E., 2004. Bird Ecology and Conservation: A Handbook of Techniques. Oxford University Press.

Syrbe, R-U., Michel, E., Walz, U., 2013. Structural indicators for the assessment of biodiversity and their connection to the richness of avifauna. Ecol. Indic. 31, 89-98.

Tabarelli, M., Aguiar, A.V., Ribeiro, M.C., Metzger, J.P., Peres, C.A., 2010. Prospects for biodiversity conservation in the Atlantic Forest: lessons from aging humanmodified landscapes. Biol. Conserv. 143, 2328-2340.

Tejeda-Cruz, C., Sutherland, W.J., 2004. Bird responses to shade coffee production. Anim. Conserv. 7 (2), 169-179.

Temple, S.A., Wiens, J.A., 1989. Bird populations and environmental changes: can birds be bio-indicators? Am. Birds 43, 260-270.

Thiollay, J.M., 2005. Effects of hunting on guianan forest game birds. Biodivers. Conserv. 14 (5), 1121-1135.
Thompson, S., Treweek, J.R., Thurling, D.J., 1997. The ecological component of environmental impact assessment: a critical review of British environmental statements. J. Environ. Plan. Manage. 40 (2), 157-172, http://dx.doi.org/10.1080/ 09640569712164.

Thompson, W.L., 2002. Towards reliable bird surveys: accounting for individuals present but not detected. Auk 119 (1), 18-25.

Uezu, A., Metzger, J.P., Vielliard, J.M.E., 2005. Effects of structural and functional connectivity and patch size on the abundance of seven Atlantic Forest bird species. Biol. Conserv. 123, 507-519.

Uezu, A., Beyer, D.D., Metzger, J.P., 2008. Can agroforest woodlots work as stepping stones for birds in the Atlantic Forest region? Biodivers. Conserv. 17 (8), 1-16.

Uezu, A., Metzger, J.P., 2011. Vanishing bird species in the Atlantic Forest: relative importance of landscape configuration, forest structure and species characteristics. Biodivers. Conserv. 20, 3627L 3643.

Valente, R.O.A., Vettorazzi, C.A., 2003. Mapeamento de uso e cobertura do solo daBacia do Rio Corumbataí, SP. Circular Técnica IPEF 196, 1-10.

Vasconcelos, M.F., 2006. Uma opinião crítica sobre a qualidade e a utilidade dos trabalhos de consultoria ambiental sobre avifauna. Atualidades Ornitol. 131, 10L 12.

Verdade, L.M., Gheler-Costa, C., Penteado, M., Dotta, G., 2012. The impacts of sugarcane expansion on wildlife in the State of São Paulo, Brazil. J. Sustain. Bioenergy Syst. 2 (4), 138-144

Victor, M.A.M., Cavalli, A.C., Guillaumon, J.R., Filho, R.S., 2005. Cem anos de devastação: revisitada 30 anos depois. Ministério do Meio Ambiente, Brasília, $72 \mathrm{pp}$.

Vielliard, J.M.E., Almeida, M.E.C., Anjos, L., Silva, W.R., 2010. Levantamento quantitativo por pontos de escruta e o indice pontual de abundância (IPA). In: Matter, S.V., Straube, F.C., Accordi, I., Piacentini, V., Cândido-Jr., J.F. (Eds.), Ornitologia e Conservação. Ciência Aplicada, Técnicas de pesquisa e Levantamento. Technical Books, Rio de Janeiro, pp. 47-60

Vitousek, P., Mooney, H., Lubchenco, J., Melillo, J., 1997. Human domination of Earth's ecosystems. Science 277 (5325), 494-499.

Walsh, J.C., Dicks, L.V., Sutherland, W.J., 2014. The effect of scientific evidence on conservation practitioners' management decisions. Conserv. Biol., http://dx.doi. org/10.1111/cobi.12370.

Watson, J.E., Whittaker, R.J., Freudenberger, D., 2005. Bird community responses to habitat fragmentation: how consistent are they across landscapes? J. Biogeogr. 32 (8), 1353-1370.

Willis, E.O., Oniki, Y., 1987. Invasion of deforested regions of Sao Paulo state by the picazuro pigeon, Columba picazuro Temminck, 1813. Ciência Cult. 39 (11), 1064-1065

Willis, E.O., Oniki, Y., 2002. Birds of a central São Paulo woodlot: 1. Censuses 1982-2000. Braz. J. Biol. 62 (2), 197-210.

Woltmann, S., 2003. Bird community responses to disturbance in a forestry concession in lowland Bolivia. Biodivers. Conserv. 12 (9), 1921-1936.

Wright, S.J., 2010. The future of tropical forests. Ann. N. Y. Acad. Sci. 1195 (1), 1-27.

Zurita, G.A., Bellocq, M.I., 2012. Bird assemblages in anthropogenic habitats: identifying a suitability gradient for native species in the Atlantic Forest. Biotropica (3), 412-419.

Zurita, G.A., Pe'er, G., Bellocq, M.I., Hansbauer, M.M., 2012. Edge effects and their influence on habitat suitability calculations: a continuous approach applied to birds of the Atlantic forest. J. Appl. Ecol. 49, 503-512. 